\title{
Focus on Fertilization
}

\section{Evidence that activation of Src family kinase is not required for fertilization-associated $\left[\mathrm{Ca}^{2+}\right]_{i}$ oscillations in mouse eggs}

\author{
Manabu Kurokawa ${ }^{1, *}$, Ken-ichi Sato ${ }^{1, *}$, Jeremy Smyth ${ }^{1,2}$, Hua Wu ${ }^{2}$, Kiyoko Fukami ${ }^{3}$, \\ Tadaomi Takenawa ${ }^{3}$ and Rafael A Fissore ${ }^{1}$ \\ ${ }^{1}$ Department of Veterinary and Animal Sciences and ${ }^{2}$ Program in Molecular and Cellular Biology, \\ University of Massachusetts, Amherst, MA 01003, Massachusetts, USA and ${ }^{3}$ Department of Biochemistry, \\ Institute of Medical Science, University of Tokyo, Tokyo, Japan
}

Correspondence should be addressed to R A Fissore; Email: rfissore@vasci.umass.edu

${ }^{*} M$ Kurokawa and $K$ Sato contributed equally to this work

K Sato is currently at Research Center for Environmental Genomics, Kobe University, Kobe, Japan; H Wu is currently at Department of Cell Biology, Harvard Medical School, Boston, MA 02115, Massachussetts, USA and K Fukami is currently at Laboratory of Genome and Biosignal, Tokyo University of Pharmacy and Life Science, Tokyo, Japan

\begin{abstract}
Recent evidence in marine invertebrate, frog, and zebrafish eggs suggests the involvement of a Src family kinase (SFK) in fertilization-induced $\mathrm{Ca}^{2+}$ release. In the present study, we have investigated whether activation of an SFK is required for initiation of intracellular $\mathrm{Ca}^{2+}\left(\left[\mathrm{Ca}^{2+}\right]_{\mathrm{i}}\right)$ oscillations in mouse fertilization. We detected a Hck-like protein and tyrosine-phosphorylated proteins in soluble and insoluble sperm fractions, respectively. However, the presence of these proteins did not correspond to the active fractions of porcine sperm extracts (pSE). Moreover, $\left[\mathrm{Ca}^{2+}\right]_{i}$ oscillations induced by pSE in mouse eggs were unaltered by pre-incubation of pSE with specific SFK inhibitors such as 4-amino-5-(4-chlorophenyl)-7-(t-butyl)pyrazol[3,4-d]-pyrimidine (PP2) or lavendustin A, despite the fact that the inhibitors were shown to be active both in vivo and in vitro. Another SFK inhibitor, peptide A, blocked oscillations when incubated with pSE prior to injection into eggs, but this inhibition required more than ten times the concentration reportedly required to inhibit SFK activity. In addition, pre-injection or pre-incubation of eggs with these inhibitors did not affect the ability of pSE to trigger $\left[\mathrm{Ca}^{2+}\right]_{i}$ oscillations in mouse eggs. Microinjection of a recombinant c-Src protein or mRNAs encoding constitutively active Src proteins did not induce $\left[\mathrm{Ca}^{2+}\right]_{i}$ release. Finally, when sperm and eggs, both of which were pre-treated with PP2, were fertilized, $\left[\mathrm{Ca}^{2+}\right]_{i}$ oscillations occurred normally. We can therefore conclude that activation of an SFK is neither necessary nor sufficient for triggering fertilization-induced $\left[\mathrm{Ca}^{2+}\right]_{i}$ oscillations.
\end{abstract}

Reproduction (2004) 127 441-454

\section{Introduction}

At fertilization the sperm initiates a series of cellular and biochemical events in the egg that are collectively referred to as egg activation. It has been demonstrated that the intracellular $\mathrm{Ca}^{2+}\left(\left[\mathrm{Ca}^{2+}\right]_{i}\right)$ release induced by the sperm is essential and sufficient for initiation of egg activation. An increasing body of evidence suggests that, upon gamete fusion, the sperm delivers a factor(s), termed sperm factor, into the egg's cytoplasm to initiate the $\mathrm{Ca}^{2+}$ signal. In support of this notion, the $\left[\mathrm{Ca}^{2+}\right]_{i}$ release induced by injection of sperm extracts is spatially and temporally similar to that at fertilization and is highly conserved across species (Wu et al. 1997, Oda et al. 1999, Parrington et al. 1999, Dong et al. 2000, Jones et al. 2000, Stricker et al. 2000, Li et al. 2001, Coward et al. 2003), although the exact mechanism utilized by sperm extracts still remains elusive. Previous studies have shown that the $\left[\mathrm{Ca}^{2+}\right]_{\mathrm{i}}$ release induced by sperm or by injection of sperm extracts involves production of inositol 1,4,5-trisphosphate $\left(\mathrm{IP}_{3}\right)$ via activation of a phospholipase C (PLC) (Stith et al. 1993, Dupont et al. 1996, Snow et al. 1996, Lee \& Shen 1998, Sato et al. 2000, Kuroda et al. 2001). $\mathrm{IP}_{3}$, in turn, leads to $\left[\mathrm{Ca}^{2+}\right]_{i}$ release from the endoplasmic reticulum by interacting with $\mathrm{IP}_{3}$ receptors (Miyazaki et al. 1992, Wu et al. 1997). 
Given this known requirement for stimulation of the $\mathrm{IP}_{3}$ pathway by the sperm or injection of sperm extracts, significant research has logically focused on the mechanism by which activation of a PLC occurs in the ooplasm. It is known that mammalian eggs express the $\beta 1, \beta 3, \gamma 1$, and $\gamma 2$ PLC isozymes, and the case for activation of an egg PLC by the fertilizing sperm was first made by Dupont et al. (1996), when they demonstrated that fertilizationinduced $\left[\mathrm{Ca}^{2+}\right]_{\mathrm{i}}$ oscillations are sensitive to antagonism by $\cup-73122$, a specific pan-PLC inhibitor. A similar inhibition was later demonstrated for sperm extract-induced oscillations (Wu et al. 2001b). However, these experiments failed to demonstrate whether the active PLC is native to the egg or is delivered by the sperm or sperm extract injection, due to ambiguity over the exact site of action of U-73122 (Yule \& Williams 1992, Walker et al. 1998). It has also been shown that sperm express multiple PLC isoforms (Mehlmann et al. 1998, Fukami et al. 2001, Wu et al. 2001b, Parrington et al. 2002 and in vitro assays have demonstrated PLC activity in sperm extracts (Jones et al. 1998, 2000, Rice et al. 2000). The case for a spermborne PLC as the key factor during fertilization-induced $\mathrm{Ca}^{2+}$ signaling was recently bolstered by the discovery of PLC $\zeta$, a novel, sperm-specific isoform that has been detected in mouse, human, and cynomolgus monkey sperm (Cox et al. 2002, Saunders et al. 2002, Swann et al. 2004 (this issue)). These studies further demonstrated that injection of mRNA encoding PLC $\zeta$ induces $\left[\mathrm{Ca}^{2+}\right]_{i}$ oscillations in mouse eggs similar to those generated by fertilization, and that immunodepletion of PLC $\zeta$ protein from sperm extracts abrogates the ability of those extracts to induce $\left[\mathrm{Ca}^{2+}\right]_{i}$ release when injected into mouse eggs. Thus, strong evidence supports the notion that PLC $\zeta$ represents the $\mathrm{Ca}^{2+}$-active factor of sperm extracts; however, the question remains as to whether PLC $\zeta$ is also the physiological factor responsible for triggering oscillations during natural fertilization. Furthermore, these findings do not rule out the possibility that a concurrent pathway(s) leading to activation of an egg PLC(s) may also function during fertilization.

One candidate pathway that may result in activation of an egg PLC is that involving protein tyrosine kinases. Recently, significant progress has been made in the study of the involvement of tyrosine kinases in triggering spermand/or sperm extract-induced $\left[\mathrm{Ca}^{2+}\right]_{i}$ release in echinoderm, ascidian, Xenopus, and zebrafish eggs, raising the possibility that a similar mechanism may also be in operation during mammalian fertilization (Giusti et al. 1999, 2000, Glahn et al. 1999, Sato et al. 1999, 2000, Abassi et al. 2000, Runft \& Jaffe 2000, Wu \& Kinsey 2000). In these studies, injection of GST fusion proteins containing the $\mathrm{SH} 2$ domains of a Src family kinase (SFK), which act as dominant negative inhibitors, blocked the sperminitiated $\mathrm{Ca}^{2+}$ signal, suggesting a role for SFKs in initiating the fertilization-induced $\mathrm{Ca}^{2+}$ signal in echinoderm eggs (Giusti et al. 2000). In addition, similar to fertilization, the $\left[\mathrm{Ca}^{2+}\right]_{i}$ release in response to $\mathrm{Src}$ protein injection was blocked by prior injection of $\mathrm{PLC} \gamma \mathrm{SH} 2$ domains (Carroll et al. 1997, 1999, Shearer et al. 1999), which implies that the sperm initiates $\left[\mathrm{Ca}^{2+}\right]_{i}$ release in these eggs by sequential activation of an SFK and PLC $\gamma$. Using a similar strategy in ascidian eggs, it has been shown that both fertilization and injection of sperm extracts trigger $\left[\mathrm{Ca}^{2+}\right]_{i}$ release by activating the same pathway that involves PLC $\gamma$ and an SFK (Runft \& Jaffe 2000). In Xenopus, pharmacological and specific SFK inhibitors have been reported to block fertilizationinduced $\mathrm{Ca}^{2+}$ release by inhibiting the SFK-dependent PLC $\gamma$ activity (Glahn et al. 1999, Sato et al. 2000, Tokmakov et al. 2002). However, differences among species as to how PLC $\gamma$ is activated by the SFK pathway have been documented. For example, it has been shown that injection of $\mathrm{PLC} \gamma \mathrm{SH} 2$ fusion proteins, which inhibit sperm- or sperm extract-triggered $\left[\mathrm{Ca}^{2+}\right]$ signals in echinoderm and ascidian eggs, do not block the sperm-initiated $\mathrm{Ca}^{2+}$ signal in Xenopus (Runft et al. 1999). Therefore, although the same signaling pathway may participate at fertilization in most species, the activation and regulation of it may be species specific.

In mammalian eggs, due to their small size and the limited sensitivity of kinase assays, the role of Src kinases following fertilization or sperm extract injection has not been characterized. In rat eggs, it has been reported that several proteins become tyrosine phosphorylated shortly after fertilization, and that c-Fyn is expressed in the egg before and after following fertilization (Ben-Yosef et al. 1998, Talmor et al. 1998). Moreover, incubation of mouse eggs with tyrosine kinase inhibitors has been shown to have limited (maybe due to the poor permeability of mouse egg membranes for these inhibitors) but significant inhibitory effects on $\mathrm{Ca}^{2+}$ responses at fertilization, suggesting the possible involvement of a tyrosine kinase(s) in mammalian fertilization (Dupont et al. 1996). Interestingly, and similar to Xenopus eggs, $\left[\mathrm{Ca}^{2+}\right]_{i}$ release at fertilization was not inhibited in mouse eggs by injection of excess PLC $\gamma \mathrm{SH} 2$ domains, suggesting that if PLC $\gamma$ participates in the sperm-initiated pathway, it is not activated by an $\mathrm{SH}_{2}$ domain-related mechanism (Mehlmann et al. 1998). Thus, given the limited investigation into the possible role of a tyrosine kinase-regulated pathway in mammalian fertilization and in light of the strong evidence in favor of such a pathway in several non-mammalian species, a thorough investigation into the possible role of tyrosine kinases, and specifically Src-related kinases, in sperm/sperm extract-induced $\left[\mathrm{Ca}^{2+}\right]_{i}$ release in mammalian eggs is warranted.

\section{Materials and Methods}

\section{Gamete collection}

MII eggs were obtained from B6D2F1 (C57BL/6) $\times$ DBA/2J) and CD1 female mice (8-12 weeks old) 
superovulated by injection of 5 IU pregnant mare serum gonadotropin (Sigma, St Louis, MO, USA) followed $48 \mathrm{~h}$ later by $5 \mathrm{IU}$ human chorionic gonadotropin (hCG; Sigma). Eggs were recovered $14 \mathrm{~h}$ post-hCG into a Hepesbuffered tyrode-lactate solution supplemented with $5 \%$ heat-treated calf serum (TL-Hepes). Cumulus cells were removed by brief treatment with $0.1 \%$ bovine testes hyaluronidase (Sigma). Mouse sperm (12- to 24-week-old B6D2F1 and CD1 male mice) collected from cauda epididymides and boar sperm collected from freshly ejaculated semen were washed twice with injection buffer $(75 \mathrm{mM}$ $\mathrm{KCl}$ and $20 \mathrm{mM}$ Hepes, $\mathrm{pH} 7.0$ ) before use.

All procedures involving live animal handling and euthanasia were performed according to standard animal protocols approved by the University of Massachusetts Animal Care Committee.

\section{Preparation of porcine sperm extracts (pSE)}

Cytosolic pSE $\left(\mathrm{pSE}^{\mathrm{C}}\right)$ were prepared as previously described (Wu et al. 2001b). Briefly, after washing, the sperm suspension was sonicated (XL2020; Heat Systems Inc., Farmingdale, NY, USA) in sperm buffer $(75 \mathrm{mM} \mathrm{KCl}$, $20 \mathrm{mM}$ Hepes, $1 \mathrm{mM}$ EDTA, $10 \mathrm{mM}$ glycerophosphate, $1 \mathrm{mM}$ dithiothreitol, $200 \mu \mathrm{M}$ phenylmethylsulfonyl fluoride (PMSF), $10 \mu \mathrm{g} / \mathrm{ml}$ pepstatin, and $10 \mu \mathrm{g} / \mathrm{ml}$ leupeptin, $\mathrm{pH}$ 7.0) at $4{ }^{\circ} \mathrm{C}$ and the lysate ultracentrifuged. The clear supernatant was concentrated with ultrafiltration membranes (Centriprep-30; Amicon, Beverly, MA, USA). These extracts were then mixed for $30 \mathrm{~min}$ at $4{ }^{\circ} \mathrm{C}$ with ammonium sulfate at $50 \%$ final saturation; the precipitates were collected by centrifugation and kept at $-80^{\circ} \mathrm{C}$. Upon use, the pellets were resuspended in injection buffer, washed, and re-concentrated with ultrafiltration membranes.

Triton $\mathrm{X}$-100 soluble sperm extracts $\left(\mathrm{pSE}^{\mathrm{TX}}\right)$ were prepared as following. After preparation of $\mathrm{pSE}^{\mathrm{C}}$, the resulting sperm pellets were thoroughly washed with sperm buffer, and then subjected to incubation with $0.1 \%$ Triton $\mathrm{X}-100$ (Sigma) in sperm buffer for $30 \mathrm{~min}$ at $4{ }^{\circ} \mathrm{C}$. After the treatment, the sperm suspension was centrifuged at $100000 \mathrm{~g}$ for $1 \mathrm{~h}$ at $4{ }^{\circ} \mathrm{C}$. The clear supernatant was collected and concentrated with ultrafiltration membranes. Following $\mathrm{pSE}^{\mathrm{TX}}$ extraction, the sperm pellets were washed and further subjected to alkaline carbonate extraction $(100 \mathrm{mM}$ $\mathrm{Na}_{2} \mathrm{CO}_{3}, \mathrm{pH} 11.5,10 \mathrm{~min}$ at $4{ }^{\circ} \mathrm{C}$; Fujiki et al. 1982) to collect high $\mathrm{pH}$-soluble sperm extracts $\left(\mathrm{pSE}^{\mathrm{pH}}\right)$. After the treatment, the sperm suspension was neutralized, centrifuged, and concentrated. Samples were aliquoted and kept at $-80^{\circ} \mathrm{C}$.

To solubilize insoluble sperm fractions in certain experiments (see Fig. 2A), the porcine sperm pellets following sonication (see above) were thoroughly mixed with five strokes using a small needle (26 gauge) in phosphate-buffered saline containing $0.5 \%$ SDS. The supernatant obtained following brief centrifugation (10000 r.p.m., $10 \mathrm{~min}$ ) was used for protein assays.

\section{Fast protein liquid chromatography columns}

pSEs were subjected to Superose 12 columns (Superose 12 HR 10/30; Amersham Biosciences Corp., Piscataway, NJ, USA) using an FPLC system as described previously (Wu et al. 1998a, 2001b). Proteins obtained from the ammonium sulfate precipitation were loaded at $4{ }^{\circ} \mathrm{C}$ onto a Superose 12 column. Proteins were eluted with elution buffer $(75 \mathrm{mM} \mathrm{KCl}, 20 \mathrm{mM}$ Hepes, $1 \mathrm{mM}$ EDTA, $200 \mu \mathrm{M}$ PMSF, $20 \mu \mathrm{g} / \mathrm{ml}$ pepstatin, and $20 \mu \mathrm{g} / \mathrm{ml}$ leupeptin, $\mathrm{pH}$ 7.0) at a flow rate of $0.1 \mathrm{ml} / \mathrm{min}$ and detected at $\mathrm{OD}_{280}$ by a UV-M monitor (Pharmacia Biotech Inc., Piscataway, NJ, USA). Fractions $(0.25 \mathrm{ml})$ were collected and concentrated for testing the $\mathrm{Ca}^{2+}$-releasing activity and for performing Western blots.

\section{Microinjection}

Microinjection procedures were as previously described (Wu et al. 1997, 1998a,b, 2001b). In brief, eggs were microinjected using Narishige manipulators (Medical Systems Corp., Great Neck, NY, USA) mounted on a Nikon Diaphot microscope (Nikon Inc., Garden City, NY, USA). Glass micropipettes were filled by suction from a microdrop containing pSE, a recombinant $\mathrm{c}$-Src protein (Cat. No. $14-117,3 \mu \mathrm{g} / \mu \mathrm{l}, 75$ units/25 $\mu \mathrm{l}$; Upstate Biotechnology, Lake Placid, NY, USA), or mRNAs. Solution was expelled into the cytoplasm of eggs by pneumatic pressure (PLI-100 picoinjector; Harvard Apparatus, Cambridge, MA, USA). The injection volume was approximately $5-10 \mathrm{pl}$ and resulted in a final intracellular concentration of the injected compounds of approximately $1-5 \%$ of the concentration in the injection pipette.

\section{Intracytoplasmic sperm injection (ICSI)}

ICSI was carried out as previously described (Kimura \& Yanagimachi 1995, Kurokawa \& Fissore 2003) using Narishige manipulators mounted on a Nikon Diaphot microscope. ICSI was performed in Hepes-buffered CZB (Chatof, Ziomek and Bavister) medium (Kimura \& Yanagimachi 1995). One part sperm suspension was mixed with one part injection buffer containing $12 \%$ polyvinyl pyrrolidone (molecular weight $360 \mathrm{kDa}$; Sigma). Sperm were delivered into the eggs' cytosol using a piezo micropipette-driving unit (Piezodrill; Burleigh Instruments Inc., Rochester, NY, USA) as described elsewhere (Kimura \& Yanagimachi 1995, Kurokawa \& Fissore 2003); a few piezo pulses were applied to puncture the egg plasma membrane following penetration of the zona pellucida. Mouse sperm heads were separated from tails by applying a few piezo pulses at the mid-piece of the sperm immediately prior to injection into the egg. In experiments using boar sperm, the heads were separated from tails by a $45-$ $60 \mathrm{~s}$ sonication period (at $4^{\circ} \mathrm{C}$ ) since piezo pulses are ineffective at disrupting these sperm (Kimura et al. 1998); sonication resulted in more than $90 \%$ of sperm heads separated from their tails. In certain experiments, porcine 
sperm were subjected to Triton X-100 or high pH extraction (see section on Preparation of porcine sperm extracts) following sonication. After such treatments, sperm were thoroughly washed with injection buffer before ICSI.

Following ICSI, injection of pSE, or treatment of eggs with $\mathrm{H}_{2} \mathrm{O}_{2}$, eggs were either used for $\left[\mathrm{Ca}^{2+}\right]_{i}$ monitoring or cultured in KSOM (potassium Simplex Optimization Medium) to evaluate activation at $36.5^{\circ} \mathrm{C}$ in a humidified atmosphere containing $5.5 \% \quad \mathrm{CO}_{2}$. Activation was assessed from the number of zygotes with extrusion of the second polar body and formation of pronuclei at $6 \mathrm{~h}$ postICSI or pSE injection.

\section{Inhibitor preparations and loading conditions}

Tyrosine kinase inhibitors, 4-amino-5-(4-chlorophenyl)-7(t-butyl)pyrazolo[3,4-d]-pyrimidine (PP2) and lavendustin A, and an inactive analogue, 4-mino-7-phenylpyrazol[3,4ad]-pyrimidine (PP3), were obtained from Calbiochem (San Diego, CA, USA). These compounds were dissolved in dimethyl sulfoxide at $5 \mathrm{mM}$ and kept at $-80^{\circ} \mathrm{C}$ until use. Peptide A (VAPSDSIQAEEWYFGKITRRE) was purchased from Calbiochem (Sato et al. 1990, Glahn et al. 1999). Peptide A9 (SDSIQAEEWYFGKIT) was prepared as previously described (Fukami et al. 1993, Sato et al. 2003). The inhibitory peptides were dissolved in injection buffer at $1 \mathrm{mM}$ and kept at $-80^{\circ} \mathrm{C}$. Upon use, the compounds were further diluted in KSOM, TL-Hepes, or injection buffer to working concentrations, and eggs and/or sperm were loaded by 30-min incubations. Pre-incubation and culture of eggs/sperm with PP2, PP3, or lavendustin A were performed in the absence of oil to avoid the possible permeability of these compounds to the oil.

\section{$\left[\mathrm{Ca}^{2+}\right]_{i}$ measurements}

$\left[\mathrm{Ca}^{2+}\right]_{\mathrm{i}}$ measurements were carried out as previously described (Kurokawa \& Fissore 2003). Eggs were loaded with $1 \mu \mathrm{M}$ fura-2 acetoxymethylester (Molecular Probes, Eugene, OR, USA) supplemented with $0.02 \%$ pluronic acid (Molecular Probes) for $20 \mathrm{~min}$ at room temperature. $\left[\mathrm{Ca}^{2+}\right]_{i}$ values were monitored using a Nikon Diaphot microscope fitted for fluorescence measurements. Eggs were either individually monitored using modified Phoscan 3.0 software (Nikon Inc.) or measured simultaneously (2 to 15 eggs) using the software Image 1/FL (Universal Imaging, Downington, PA, USA) and an SIT camera (Dage-MTI, Michigan City, IN, USA) coupled to an amplifier (Video Scope International Ltd, Sterling, VA, USA). $\left[\mathrm{Ca}^{2+}\right]_{i}$ values are reported as the ratios of $340 / 380 \mathrm{~nm}$ fluorescence (F340/380). Fluorescence ratios were obtained every 4-20s depending on the experiments.

\section{Western blotting}

Western blotting was carried out as previously described (He et al. 1997, Jellerette et al. 2000). Rabbit polyclonal antibodies raised against Blk (sc-329), Fgr (sc-130), Hck (sc-72), Lyn (sc-15), Src (sc-19), Yes (sc-14), and anti-phosphotyrosine mouse monoclonal antibody (PY99, sc-7020) were purchased from Santa Cruz Biotechnology (Santa Cruz, CA, USA). Anti-Lck rabbit polyclonal antibody (06135) was obtained from Upstate Biotechnology. Rabbit polyclonal antibodies against Abl (PC-01) and Fyn (PC-32), and mouse monoclonal antibodies against c-Src (mAb327, OP-07) and phosphorylated tyrosine 416 of c-Src (Src ${ }^{\text {pY416, }}$ 44-660) were from Oncogene Science (San Diego, CA, USA). The anti-pepY antibody was raised against a synthetic peptide, pepY, which corresponds to residues 410428 of chicken c-Src (Fukami et al. 1993). Mouse monoclonal antibody raised against the unphosphorylated C-terminus of Src/Fyn/Yes, termed clone 12, was a kind gift from Dr Owada, Kyoto Pharmaceutical University, Japan.

Samples of 40 eggs were collected after treatment with $10 \mu \mathrm{M} \mathrm{H} \mathrm{H}_{2} \mathrm{O}_{2}$ (10 min post-treatment) or injection of mRNAs encoding the Src mutants (6 h post-injection) into SDS sample buffer. For analysis of pSE, $10 \mu \mathrm{g}$ protein samples were loaded to each lane. Protein samples were subjected to $10 \%$ SDS-PAGE and then transferred onto nitrocellulose membranes (Micron Separation, Westboro, MA, USA) for $1 \mathrm{~h}$ at $4{ }^{\circ} \mathrm{C}$. Following incubation with dry milk or bovine serum albumin, the membranes were probed with a primary antibody (see above) and then an appropriate horseradish peroxidase-labeled secondary antibody (170-6515/170-6516; BioRad, Hercules, CA, USA). Immunoreactivity was detected using chemiluminescence reagents (NEN Life Science Products, Boston, MA, USA) and the Kodak Image Station 440CF (NEN Life Science Products).

\section{In vitro protein kinase assays}

In vitro SFK assays were performed based on immunoblotting analysis. Eight microliters (24 ng) of recombinant Src (Cat. no. 14-117; Upstate Biotechnology) was mixed with $2 \mu \mathrm{l} 100 \mu \mathrm{M}$ compound (lavendustin A, PP2, or PP3) in the presence of $15 \mu \mathrm{l}$ kinase buffer $\left(0.5 \mu \mathrm{l} 250 \mathrm{mM} \mathrm{MgCl}_{2}\right.$, $5 \mu \mathrm{l} 100 \mathrm{mM} \mathrm{KCl}, 50 \mu \mathrm{M}$ Tris (pH 7.5), $2.5 \mu \mathrm{l} 10 \mathrm{mM}$ ATP, and $7 \mu \mathrm{H}_{2} \mathrm{O}$ ). The reaction was allowed to proceed for $10 \mathrm{~min}$ at $30^{\circ} \mathrm{C}$, after which SDS-PAGE and Western blotting were carried out to detect Src protein and $\mathrm{Src}^{\mathrm{pY} 416}$.

Likewise, in vitro tyrosine kinase assays were carried out as follows. Ten microliters of pSE $(0.5 \mu \mathrm{g} / \mu \mathrm{l})$ were mixed with $10 \mu \mathrm{l}$ kinase buffer and $5 \mu \mathrm{l}$ of either $50 \mu \mathrm{M}$ PP2 or PP3. Following the reaction $\left(10 \mathrm{~min}, 30^{\circ} \mathrm{C}\right)$, the samples were subjected to SDS-PAGE and Western blot using the anti-phosphotyrosine antibody (PY99).

\section{In vitro transcription}

The plasmids encoding constitutively active mutants of chicken c-Src (Y527F and E378G) were kind gifts from Dr Joan S Brugge (Harvard Medical School, Boston, MA, USA). The DNA sequence containing the $5^{\prime}$ end of PLC $\zeta$ $(\sim 360 \mathrm{bp})$ was isolated from mouse testis by RT-PCR. The 
amplified $5^{\prime}$ fragment was then subcloned into a vector containing a truncated construct of mouse PLC $\zeta$ (accession no. AK006672, a gift from RIKEN; Kouchi et al. 2004). Full-length mouse PLC $\zeta$ was cloned into pBluescript $\mathrm{KS}(-)$ vector and complete insertion of full-length PLC $\zeta$ was confirmed by DNA sequencing. The mRNAs were produced as previously described (Fissore et al. 1996). In brief, the cDNAs were linearized with the appropriate restriction enzyme, and transcribed in vitro using the mMessagemMachine capping kit (Ambion, Austin, TX, USA). Poly(A) tails of approximately $150-200 \mathrm{bp}$ were added to the fulllength transcripts using the Poly(A) Kit (Ambion), and capped and tailed mRNAs were purified from the reaction mixture using the MEGAclear Kit (Ambion).

\section{Results}

\section{A Hck-like protein is present in pSE}

We and others have previously shown that injection of $\mathrm{pSE}^{\mathrm{C}}$ into mouse MII eggs is able to trigger $\left[\mathrm{Ca}^{2+}\right]_{i}$ oscillations that are similar to those observed at fertilization (Wu et al. 1997) (see Fig. 4A for an example). To ascertain whether or not $\mathrm{pSE}^{\mathrm{C}}$ contains an SFK and, further, to begin to address the possibility that an SFK may represent the $\mathrm{Ca}^{2+}$-releasing factor in $\mathrm{pSE}^{\mathrm{C}}$, we performed Western blotting on $\mathrm{pSE}^{\mathrm{C}}$ using anti-Src family kinase antibodies. Among the various antibodies tested, including anti-Lyn, Blk, Fgr, Lck, Abl (non-SFK), Src, Yes, Lyn, Fyn, and Hck (see Materials and Methods), only the anti-Hck antibody detected a protein band of around $60 \mathrm{kDa}$ in $\mathrm{pSE}^{\mathrm{C}}$ (Fig. 1A); the same antibody recognized a Hck-like protein in mouse somatic cells (not shown). Importantly, the molecular size of this protein corresponded to that of a protein band recognized by anti-Src ${ }^{\text {pY416 }}$ antibody, a specific antibody against phosphotyrosine 416 of c-Src (Fig. 1A), suggesting that this $60 \mathrm{kDa}$ protein is a Src family protein, most likely Hck. To determine whether the localization of this Hcklike protein is specific to active $\mathrm{pSE}^{\mathrm{C}}, \mathrm{pSE}^{\mathrm{C}}$ was fractionated through a Superose 12 column (Fig. 1B), and Western blotting was performed using the anti-Hck antibody. Western blotting results showed that the Hck-like protein was pre-

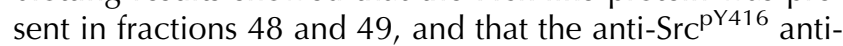
body also detected the $60 \mathrm{kDa}$ band in the same fractions (Fig. 1C; arrows), further supporting the idea that the $60 \mathrm{kDa}$ protein present in $\mathrm{pSE}^{\mathrm{C}}$ (Fig. 1A) represents Hck kinase. Interestingly, however, this Hck-like protein only localized in fractions 48 and 49, whereas $\mathrm{Ca}^{2+}$-releasing activity was found in fractions $47-50$, indicating that, if the $\left[\mathrm{Ca}^{2+}\right]_{i}$ oscillation-inducing factor is a single molecule, then this Hck-like protein is unlikely to be the candidate.

\section{Tyrosine-phosphorylated proteins mainly localize in less soluble sperm fractions}

Since the presence of Src family kinases can also be indirectly measured by detection of tyrosine-phosphorylated proteins, we conducted in vitro phosphotyrosine
A

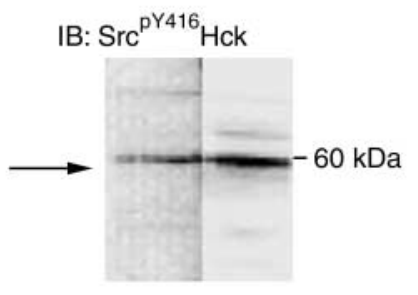

B
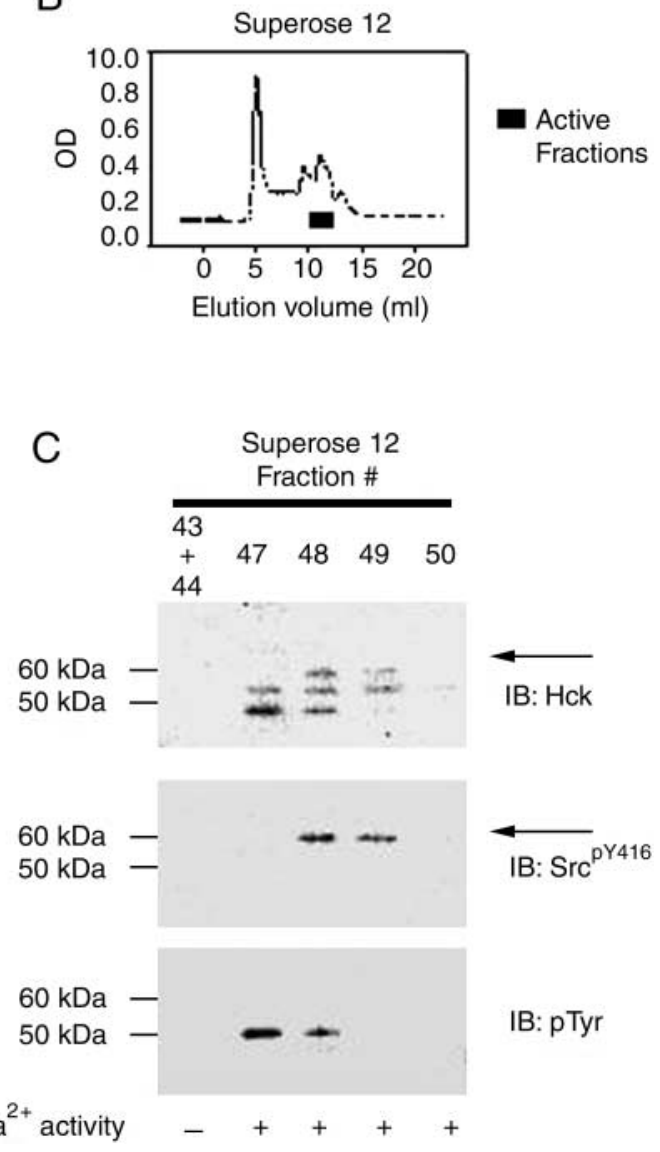

Figure 1 The Src family kinase Hck is detectable in $\mathrm{pSE}^{\mathrm{C}}$. (A) A protein band of approximately $60 \mathrm{kDa}$ from $\mathrm{pSE}^{\mathrm{C}}$ is detectable by immunoblotting (IB) with an anti-Src ${ }^{\text {pY416 }}$ antibody, which recognizes phosphotyrosine 416 of c-Src (left panel). This protein is likely to be Hck, since a band of the same size is also recognized by an anti-Hck antibody (right panel). (B) Superose 12 fractionation of $\mathrm{pSE}^{\mathrm{C}}$, followed by Western blotting $(\mathrm{C})$ reveals that the $60 \mathrm{kDa}$ protein recognized by anti-Hck (upper panel) and anti-Src ${ }^{\mathrm{pY} 416}$ antibodies (middle panel) elutes in fractions 48 and 49 (arrows indicate the locations of the $60 \mathrm{kDa}$ bands). In contrast an anti-phosphotyrosine antibody (pTyr) recognized a lower molecular weight band of approximately $55 \mathrm{kDa}$ in fractions 47 and 48 (lower panel). The lowermost line indicates Superose 12 fractions that exhibited $\mathrm{Ca}^{2+}$-releasing activity when injected into mouse eggs (indicated by + ). $\mathrm{Ca}^{2+}$-active fractions are also indicated by a solid bar in the elution profile in (B). Note that fractions with $\mathrm{Ca}^{2+}$ activity do not necessarily correspond with fractions that contain either the $60 \mathrm{kDa}$ or the $55 \mathrm{kDa}$ protein bands (i.e. fraction 50). 
assays using $\mathrm{pSE}^{\mathrm{C}}$ and porcine sperm pellets that resulted after soluble $\mathrm{pSE}^{\mathrm{C}}$ preparation (see Materials and Methods). As shown in Fig. 2A, miniscule amounts of tyrosine-phosphorylated proteins were detected in $\mathrm{pSE}^{\mathrm{C}}$. When further examined in Superose 12 column-eluted $\mathrm{pSE}^{\mathrm{C}}$, a tyrosine-phosphorylated protein was found in fractions 47 and 48 (Fig. 1C, bottom panel). However, the size of this molecule (approximately $55 \mathrm{kDa}$ ) was smaller than that of Src kinases (approximately $60 \mathrm{kDa}$; also see Fig. 1C, top and middle panels). Moreover, similar to the $60 \mathrm{kDa}$ protein, the tyrosine-phosphorylated protein of $55 \mathrm{kDa}$ was not found in all active $\mathrm{pSE}^{\mathrm{C}}$ fractions. Taken together, these results indicate that a tyrosine-phosphorylated protein present in sperm, including a Src kinase and substrate, may not be an active component of $\left[\mathrm{Ca}^{2+}\right]_{i}$ oscillation-inducing sperm extracts.

Interestingly, however, we found that the sperm pellets that result from the $\mathrm{pSE}^{\mathrm{C}}$ extraction procedure still
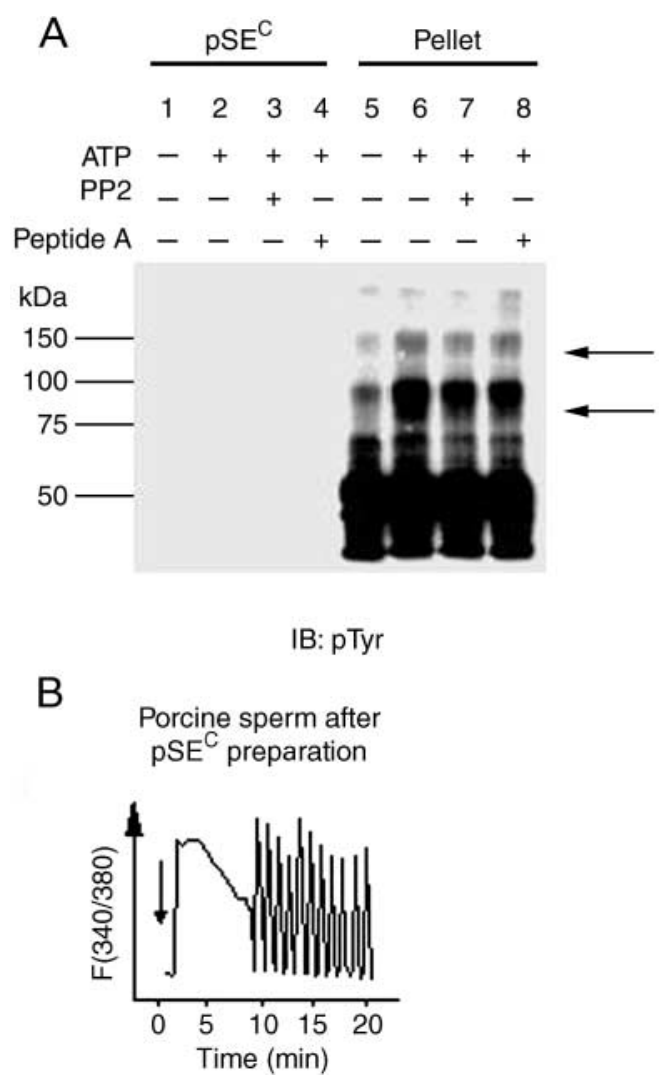

Figure 2 The pellet resulting from extraction of $\mathrm{pSE}^{\mathrm{C}}$ contains significant phosphotyrosine residues and exhibits $\mathrm{Ca}^{2+}$-releasing activity. (A) Phosphorylated proteins, as detected by the anti-pTyr antibody, are only weakly detectable in $\mathrm{pSE}^{\mathrm{C}}$ (lanes $1-4$ ), whereas multiple protein bands are readily visible in the pellet that results from $\mathrm{pSE}^{\mathrm{C}}$ preparation (lanes 5-8). Moreover, addition of ATP to the pellet increases the intensities of several of these bands (lane 6, see arrows), and these increases are significantly reduced by addition of $10 \mu \mathrm{M}$ PP2 (lane 7), or $10 \mu \mathrm{M}$ peptide A (lane 8 ). (B) Injection of a single pig sperm isolated from the pellet into a mouse egg induces high frequency $\left[\mathrm{Ca}^{2+}\right]_{i}$ oscillations. The arrow indicates the time of sperm injection; the graph is representative of nine replicates. contained a significant amount of tyrosine-phosphorylated proteins (Fig. 2A). Moreover, in some proteins, tyrosine phosphorylation appeared to be up-regulated in an ATP-dependent manner and down-regulated in the presence of PP2 or peptide A, specific Src kinase inhibitors (Fig. 2A, arrows), suggesting the presence of active Src kinases in the pellets. Importantly, when microinjected into mouse eggs, a single sperm head from the pellet was still capable of inducing $\left[\mathrm{Ca}^{2+}\right]_{i}$ oscillations (Fig. 2B) that were similar to those triggered by injection of an intact sperm head (data not shown), indicating that a significant amount of $\left[\mathrm{Ca}^{2+}\right]_{i}$ oscillation-inducing factor still remains associated with the sperm pellet.

To fully extract the $\mathrm{Ca}^{2+}$-releasing activity from the sperm, we sequentially treated porcine sperm with sonication, Triton $\mathrm{X}(\mathrm{TX})$, and high $\mathrm{pH}$ buffer, and the resulting supernatants collected after each treatment were named $\mathrm{pSE}^{\mathrm{C}}$ (see above), TX-soluble extracts $\left(\mathrm{pSE}^{\mathrm{TX}}\right.$ ) and high $\mathrm{pH}$-soluble extracts $\left(\mathrm{pSE}^{\mathrm{pH}}\right.$ ) respectively. As shown in Fig. $3 \mathrm{~A}$, injection of $\mathrm{pSE}^{\mathrm{TX}}$ and $\mathrm{pSE}^{\mathrm{pH}}$ into mouse eggs induced $\left[\mathrm{Ca}^{2+}\right]_{i}$ oscillations with similar specific activity (a protein concentration of $0.5 \mu \mathrm{g} / \mu \mathrm{l}$ ) to that of $\mathrm{pSE}^{\mathrm{C}}$. More importantly, only after treatment with high $\mathrm{pH}$ did the sperm completely lose the ability to induce $\left[\mathrm{Ca}^{2+}\right]_{i}$ oscillations (Fig. 3A). Taken together, these results demonstrated that $\left[\mathrm{Ca}^{2+}\right]_{\mathrm{i}}$ oscillation-inducing sperm factor, including both soluble and less soluble components, was fully released from the sperm and recovered into the supernatant by our extraction procedure.

Western blot analysis revealed that tyrosine-phosphorylated proteins were exclusively present in $\mathrm{pSE}^{\mathrm{TX}}$ and $\mathrm{pSE}^{\mathrm{pH}}$ (Fig. 3B). To examine whether or not any tyrosinephosphorylated proteins localize in the active fractions, $\mathrm{pSE}^{\mathrm{pH}}$ was eluted into five fractions (F1-F5) through a Superose 12 column (Fig. $3 \mathrm{C}$ ), and $\left[\mathrm{Ca}^{2+}\right]_{i}$ oscillationinducing activity in each fraction was tested by microinjection into mouse eggs. As shown in Fig. 3D, tyrosine-phosphorylated proteins only localized in inactive $\mathrm{F} 1$ and $\mathrm{F} 2$, whereas $\mathrm{F} 3$ and $\mathrm{F} 4$, which had $\left[\mathrm{Ca}^{2+}\right]_{\mathrm{i}}$ oscillation-inducing activity, did not contain tyrosinephosphorylated proteins.

\section{SFK inhibitor-treated $p S E^{C}$ induces $\left[\mathrm{Ca}^{2+}\right]_{i}$ oscillations}

In the above experiments we could not detect SFKs or tyrosine-phosphorylated proteins specifically in the active pSE fractions. To further evaluate the requirement of activation of a Src family kinase for initiation of $\left[\mathrm{Ca}^{2+}\right]_{i}$ oscillations and egg activation in the mouse, we tested whether the addition of specific Src/tyrosine kinase inhibitors is capable of inhibiting $\mathrm{pSE}^{\mathrm{C}}$-induced $\left[\mathrm{Ca}^{2+}\right]_{i}$ oscillations (Fig. 4A) and egg activation. As shown in Fig. 4B, incubation and co-injection of $\mathrm{pSE}^{\mathrm{C}}$ with $200 \mu \mathrm{M}$ PP2 failed to block oscillations induced by injection of $\mathrm{pSE}^{\mathrm{C}}$. Likewise, treatment of $\mathrm{pSE}^{\mathrm{C}}$ with $200 \mu \mathrm{M}$ lavendustin $\mathrm{A}$, a tyrosine kinase inhibitor, did not have any effects on initiation of $\left[\mathrm{Ca}^{2+}\right]_{i}$ oscillations and activation of the eggs (data not 
A

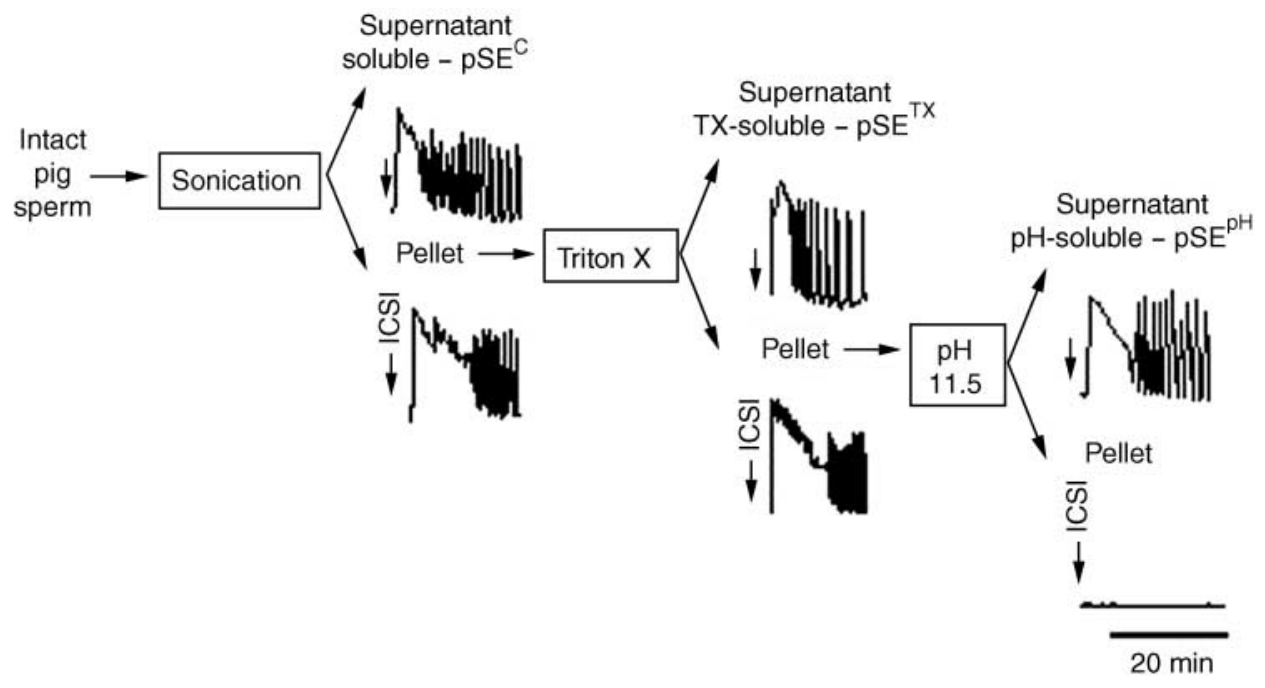

B

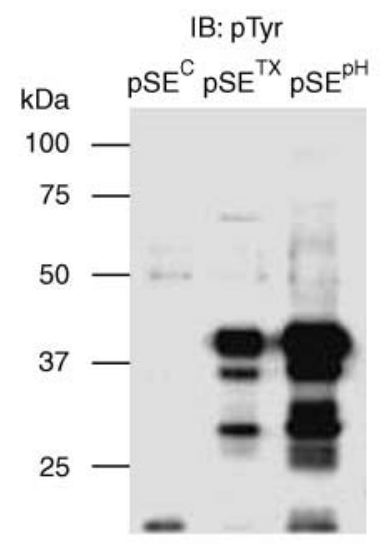

C

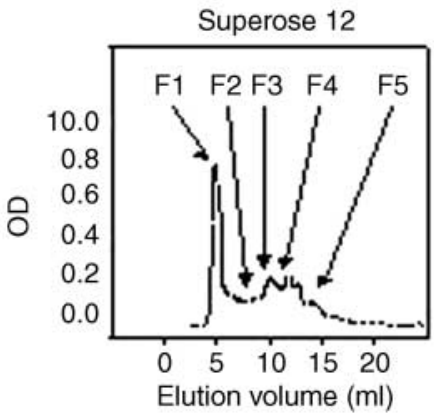

IB: pTyr

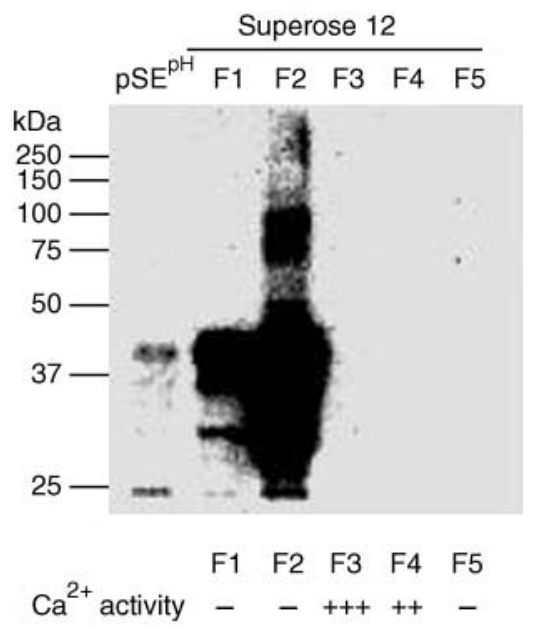

Figure 3 Full extraction of $\mathrm{Ca}^{2+}$-releasing activity from porcine sperm indicates that activity does not correlate with the presence of tyrosinephosphorylated proteins. (A) Porcine sperm were sequentially treated with sonication, Triton $\mathrm{X}$, and alkaline $\mathrm{pH}$ of 11.5 , and in each case the resulting supernatant and a single sperm from the pellet were injected into mouse eggs. A representative $\left[\mathrm{Ca}^{2+}\right]_{i}$ graph for each injection is shown. Note that only in the case of high $\mathrm{pH}$ treatment was the $\mathrm{Ca}^{2+}$-releasing activity fully released from the sperm pellet into the supernatant. (B) Immunoblotting with the anti-pTyr antibody of supernatants resulting from sonicated, Triton X-100- and high pH-treated sperm indicate that tyrosine-phosphorylated proteins are present predominantly in the latter two fractions, with the highest levels detectable in the alkaline $\mathrm{pH}$ extraction. (C) Superose 12 fractionation of the high $\mathrm{pH}$ extraction, followed by Western blotting with the anti-pTyr antibody (D) indicates that tyrosine-phosphorylated proteins elute in fractions F1 and F2, in contrast to fractions F3 and F4 which exhibited Ca ${ }^{2+}$-releasing activity when injected into mouse eggs (indicated by + in the lowermost line; fractions with more + symbols indicate higher frequency of oscillations).

shown). To confirm that these inhibitors were indeed active, in vitro kinase assays were performed. As shown in Fig. 4F, a recombinant Src protein was in vitro auto-phosphorylated at $\mathrm{Tyr}^{416}$ in the presence of ATP as revealed by the anti-Src ${ }^{\text {PY416 }}$ antibody. PP2 and lavendustin A, but not PP3, the inactive analog of PP2, were both capable of inhibiting this phosphorylation, indicating that the inhibitors used were active. It is worth noting that these inhibitors were shown to prevent fertilization-induced $\mathrm{Ca}^{2+}$ release and egg activation in Xenopus laevis, and that the concentrations of these compounds used in our studies were equal to, or much higher than, those reported in the Xenopus studies (Glahn et al. 1999, Sato et al. 2002). Therefore, these results suggested that activation of SFKs present in sperm is unlikely to be necessary for initiation of $\left[\mathrm{Ca}^{2+}\right]_{i}$ oscillations and egg activation in mouse eggs.

In contrast, however, we found that a specific Src kinase inhibitory peptide, peptide A, significantly blocked the ability of $\mathrm{pSE} \mathrm{C}^{\mathrm{C}}$ to trigger $\left[\mathrm{Ca}^{2+}\right]_{i}$ oscillations in mouse eggs when pre-incubated with $\mathrm{pSE}^{\mathrm{C}}$ (Fig. 4C). Pre-incubation of 
A

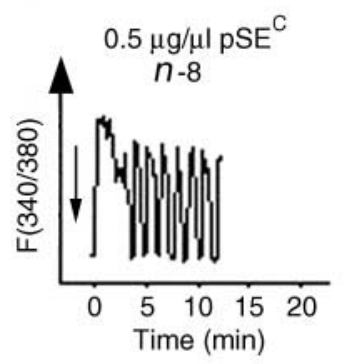

B

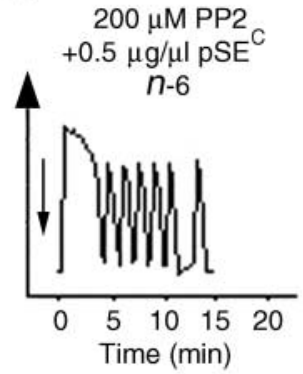

C

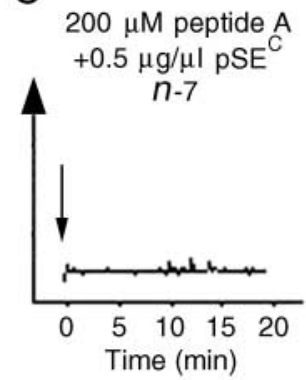

D

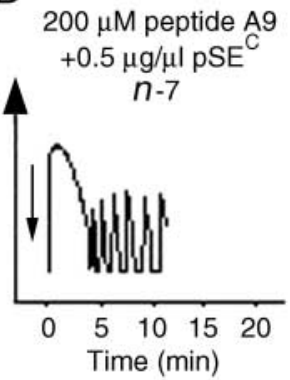

E

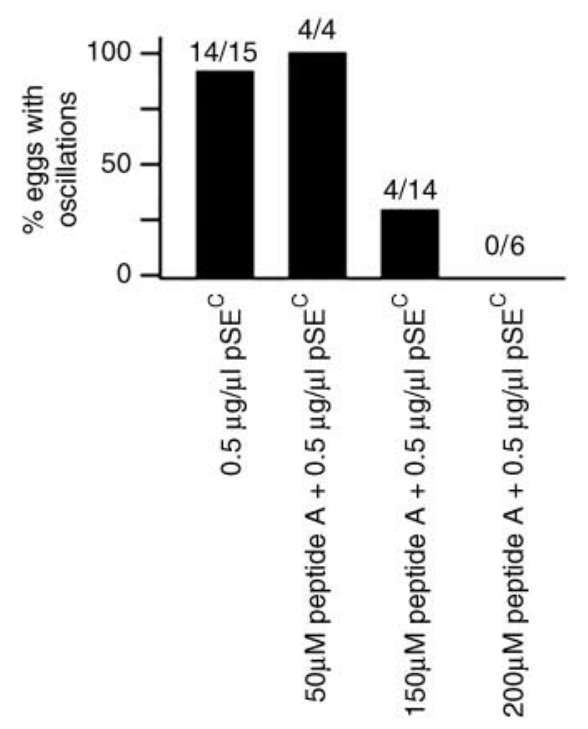

$\mathrm{F}$

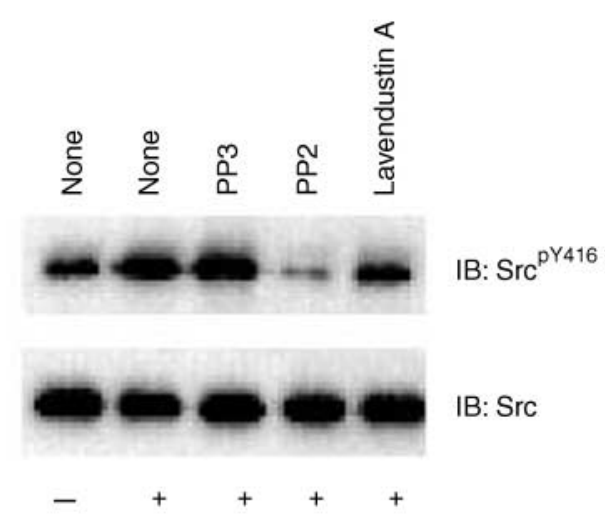

Figure $4 \mathrm{pSE}^{\mathrm{C}}$-induced $\mathrm{Ca}^{2+}$ oscillations are blocked by pre-incubation with peptide $\mathrm{A}$, but not with PP2. pSE ${ }^{\mathrm{C}}$ treated with $200 \mu \mathrm{M}$ PP2 induces oscillations when injected into mouse eggs (B) similar to those induced by untreated $\mathrm{pSE}^{\mathrm{C}}$ (A). In contrast, treatment of $\mathrm{pSE}^{\mathrm{C}}$ with $200 \mu \mathrm{M}$ peptide $A$ prevents the ability of $\mathrm{pSE}^{\mathrm{C}}$ to generate oscillations $(\mathrm{C})$, whereas the control peptide, $\mathrm{A} 9$, is ineffective (D). Arrows indicate time of injection; numbers of replicates are shown in each graph. (E) Percentage of eggs that exhibited $\left[\mathrm{Ca}^{2+}\right]_{i}$ oscillations when injected with pSE ${ }^{\mathrm{C}}$ treated with peptide A at various concentrations. (F) Recombinant Src protein was autophosphorylated in vitro in the presence of ATP, as revealed by immunoblotting with the anti-Src ${ }^{\mathrm{PY} 416}$ antibody (upper panel). This phosphorylation was significantly reduced in the presence of $10 \mu \mathrm{M}$ PP2 and, to a lesser extent, $10 \mu \mathrm{M}$ lavendustin A. Immunoblotting with the anti-Src antibody (lower panel) indicates equal loading of Src protein in each lane.

$\mathrm{pSE}^{\mathrm{C}}$ with the control peptide A9, which lacks three amino acids of both $\mathrm{C}$ - and $\mathrm{N}$-terminus present in peptide A and does not inhibit Src kinase activity, failed to prevent $\mathrm{pSE}^{\mathrm{C}}$-induced $\left[\mathrm{Ca}^{2+}\right]_{i}$ oscillations (Fig. 4D), indicating that the inhibitory effect of peptide $A$ is specific and is not a result of toxicity or high protein concentrations. As shown in Fig. 4E, the inhibitory effect of peptide A was concentration dependent and, to fully inhibit $\mathrm{pSE}^{\mathrm{C}}$-induced $\left[\mathrm{Ca}^{2+}\right]_{i}$ oscillations, $200 \mu \mathrm{M}$ peptide $\mathrm{A}$ was required. This contradicts the above results obtained by the other SFK inhibitors. Nevertheless, it is possible that there is a homologous domain in the sperm factor molecule(s) to the peptide A-binding site in SFKs so that this peptide could inhibit the activity of the putative active molecule in the extracts (see Discussion).

\section{Injection of a c-Src protein or mRNAs encoding active Src mutants is unable to induce $\left[\mathrm{Ca}^{2+}\right]_{i}$ oscillations in mouse eggs}

To evaluate whether activation of a Src family kinase per se is sufficient to induce $\left[\mathrm{Ca}^{2+}\right]_{i}$ oscillations in mouse eggs, we microinjected an active recombinant c-Src protein or mRNAs encoding two different constitutively active mutants of c-Src, Src ${ }^{\mathrm{Y} 27 \mathrm{~F}}$ and $\mathrm{Src}^{\mathrm{E} 378 \mathrm{G}}$. As shown in Fig. 5, injection of neither the recombinant c-Src $(3.0 \mu \mathrm{g} / \mu \mathrm{l}$; it was the highest concentration that we could possibly inject) nor the mRNAs (Fig. 5D and C) induced $\left[\mathrm{Ca}^{2+}\right]_{i}$ release in mouse eggs, whereas injection of $\mathrm{pSE}^{\mathrm{C}}$ $(0.5 \mu \mathrm{g} / \mu \mathrm{l})$ (Fig. 5A) or a single mouse sperm (Fig. 5B) triggered $\left[\mathrm{Ca}^{2+}\right]_{i}$ oscillations. Moreover, none of the eggs injected with the recombinant protein or the mRNAs 
A

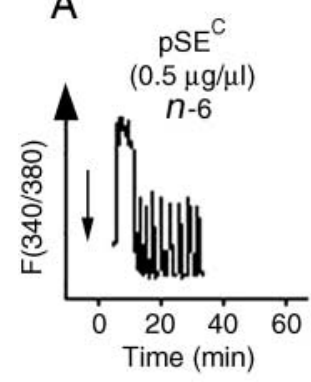

D

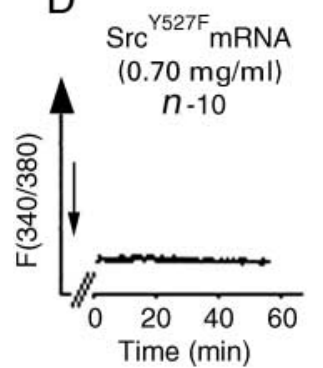

B

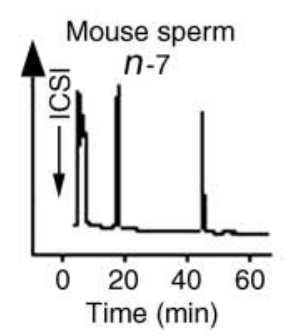

E

$\mathrm{Src}^{\mathrm{E} 378 \mathrm{mRNA}}$

$(0.74 \mathrm{mg} / \mathrm{ml})$

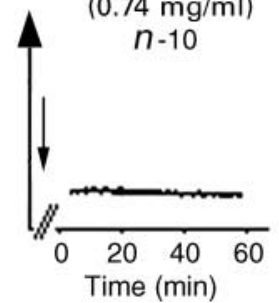

C

Recombinant cSrc

$(30 \mu \mathrm{g} / \mu \mathrm{l})$

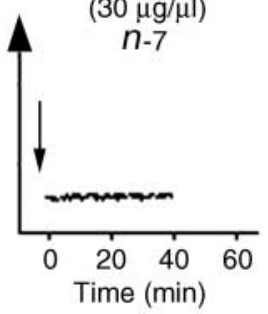

F

PLC mRNA

$(0.15 \mathrm{mg} / \mathrm{ml})$

$n-5$

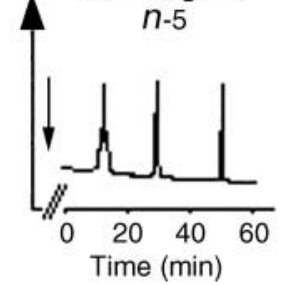

G

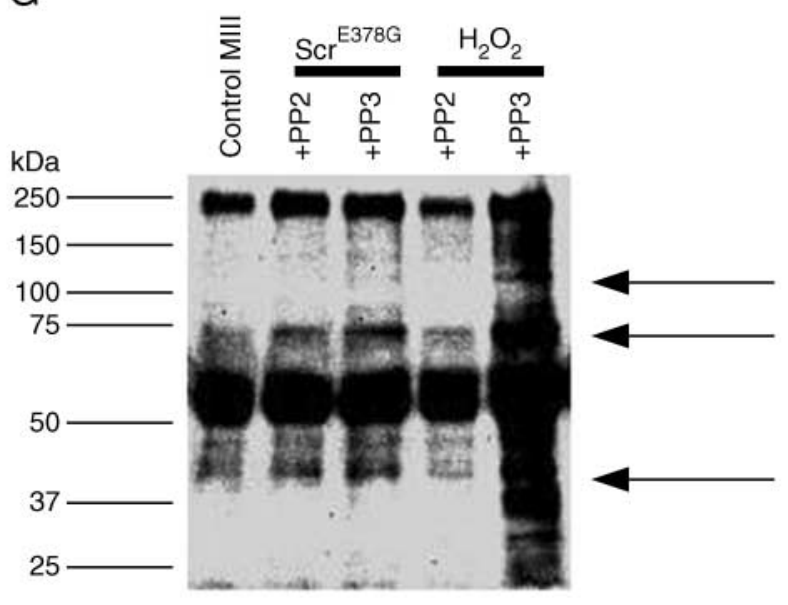

IB: pTyr
Figure $5 \mathrm{Src}$ is not sufficient to induce $\left[\mathrm{Ca}^{2+}\right]_{i}$ oscillations in mouse eggs. Injection of mouse eggs with $\operatorname{pSE}^{\mathrm{C}}(\mathrm{A})$ or a single mouse sperm (B) triggers $\left[\mathrm{Ca}^{2+}\right]_{\mathrm{i}}$ oscillations, whereas injection of either recombinant c-Src (C), Src ${ }^{\mathrm{Y} 527 \mathrm{~F}}$ mRNA (D), or $\mathrm{Src}^{\mathrm{E} 378 \mathrm{G}} \mathrm{mRNA}(\mathrm{E})$ is unable to do so. Injection of PLC $\zeta$ mRNA (F) induces oscillations similar to those generated by a single mouse sperm. Arrows indicate time of injections; numbers of replicates are shown in each graph. (G) Lysates of eggs injected with $\mathrm{Src}^{\mathrm{E} 378 \mathrm{G}}$ mRNA or treated with $10 \mu \mathrm{M} \mathrm{H}_{2} \mathrm{O}_{2}$ for $10 \mathrm{~min}$, in the presence of $5 \mu \mathrm{M}$ PP2 or PP3, were subjected to Western blotting with the anti-pTyr antibody. In the presence of PP3, the phosphotyrosine content of several protein bands (see arrows) increased as a result of $\mathrm{Src}^{\mathrm{E} 378 \mathrm{G}}$ mRNA injection or $\mathrm{H}_{2} \mathrm{O}_{2}$ treatment compared with MII controls, and this increase was prevented in the presence of PP2. Note that the arrows point at the bands that are likely substrates of SFKs, but they do not denote SFKs themselves. exhibited signs of egg activation, such as extrusion of the second polar body or pronuclear formation (data not shown). As shown in Fig. 4F, the recombinant Src protein was auto-phosphorylated at $\mathrm{Tyr}^{416}$ in vitro, indicating that the recombinant protein used was functional. In addition, mouse eggs injected with mRNA encoding $\operatorname{Src}^{\mathrm{E3} 78 \mathrm{G}}$ exhibited an increase in protein phosphotyrosine content, and this phosphorylation was inhibited in the presence of PP2, but not PP3 (Fig. 5G), suggesting that these introduced mRNAs were translated and generated active proteins in the eggs. As a positive control, we microinjected into mouse eggs mRNA encoding PLC $\zeta$, a novel candidate of the sperm's $\left[\mathrm{Ca}^{2+}\right]_{i}$ oscillation-inducing factor (Saunders et al. 2002). As shown in Fig. 5F, microinjection of PLCל mRNA initiated persistent $\left[\mathrm{Ca}^{2+}\right]_{i}$ oscillations similar to those induced by fertilization (Fig. 5B), and the injected eggs extruded the second polar body and formed a pronucleus $(n=10)$.

\section{pSE induces $\left[\mathrm{Ca}^{2+}\right]_{i}$ oscillations in mouse eggs treated with an SFK inhibitor}

To investigate the possible involvement of SFKs present in eggs, mouse eggs were first injected with $500 \mu \mathrm{M}$ PP2, lavendustin A, or peptide A (concentration in the pipette; results in an intracellular concentration of approximately $5-10 \mu \mathrm{M})$ followed by injection of $0.5 \mu \mathrm{g} / \mu \mathrm{l} \mathrm{pSE}{ }^{\mathrm{C}}$. As shown in Fig. 6A, C, D and $E$ injection of these compounds did not affect the ability of $\mathrm{pSE}^{\mathrm{C}}$ to induce $\left[\mathrm{Ca}^{2+}\right]_{\mathrm{i}}$ oscillations. Moreover, when eggs were pre-incubated in $5 \mu \mathrm{M}$ PP2 for 60 min prior to $\mathrm{pSE}^{\mathrm{C}}$ injection, $\mathrm{pSE}^{\mathrm{C}}$-induced $\left[\mathrm{Ca}^{2+}\right]_{i}$ oscillations occurred normally (Fig. 6A and B). 
A

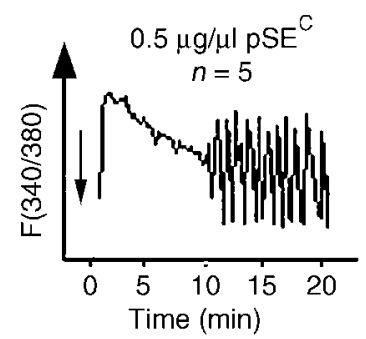
B $0.5 \mu \mathrm{g} / \mu \mathrm{lpSE} \mathrm{C}^{\mathrm{C}}$ with $5 \mu \mathrm{M}$ PP2
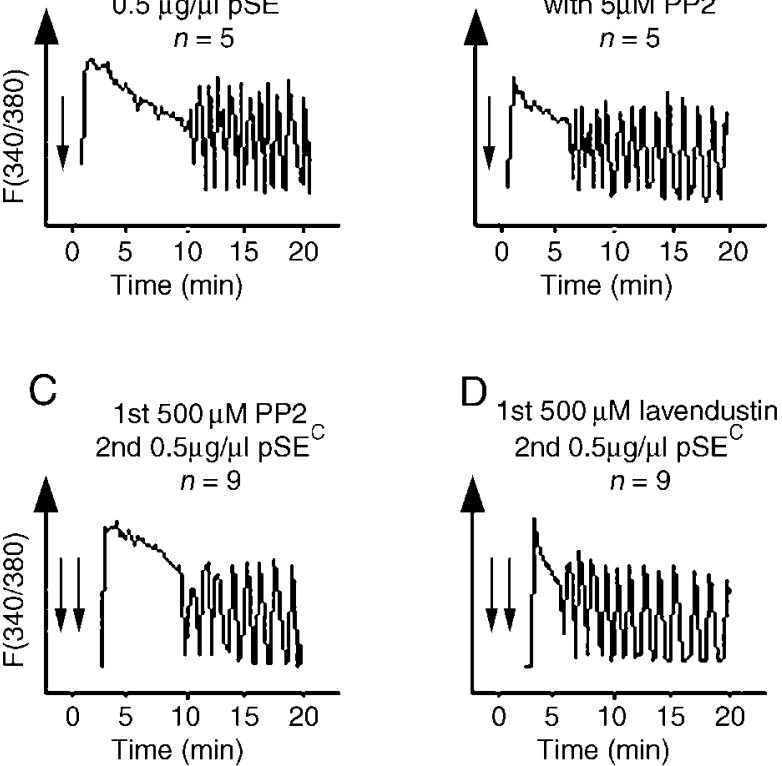

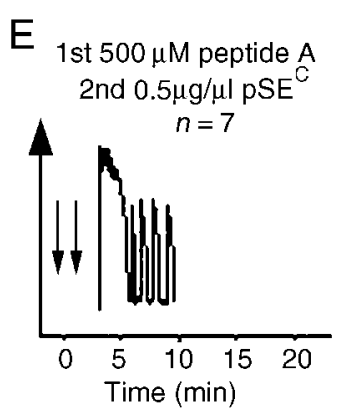

A

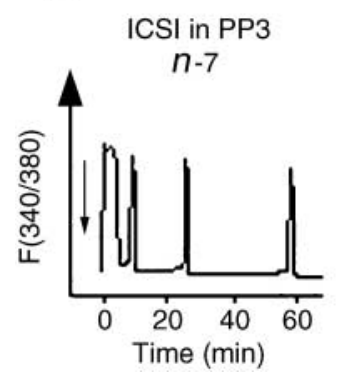

Figure 6 Treatment of eggs with Src/tyrosine kinase inhibitors does not prevent induction of $\left[\mathrm{Ca}^{2+}\right]_{i}$ oscillations by $\mathrm{pSE}^{\mathrm{C}}$. Injection of $\mathrm{pSE}^{\mathrm{C}}$ into eggs pre-incubated with PP2 generates $\left[\mathrm{Ca}^{2+}\right]_{i}$ oscillations (B) comparable with those seen in controls (A). To avoid drug permeability, in the next series of experiments the inhibitors were microinjected. Pre-injection of eggs with PP2 (C), lavendustin A (D), or peptide $A(E)$ does not prevent induction of $\left[\mathrm{Ca}^{2+}\right]_{i}$ oscillations by $\mathrm{pSE}^{\mathrm{C}}$ injection. The first arrow in each graph indicates the time of inhibitor injection, while the second arrow indicates $\mathrm{pSE}^{\mathrm{C}}$ injection. The injection of $\mathrm{pSE}^{\mathrm{C}}$ occurred within 30 min of the inhibitor injection. The numbers of replicates are shown in each graph.

B

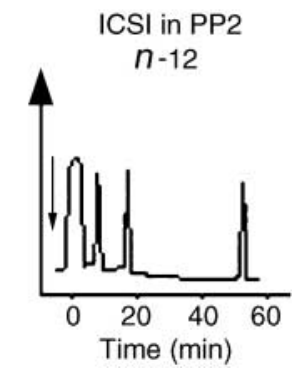

Previously, we have demonstrated using Xenopus eggs that $\mathrm{H}_{2} \mathrm{O}_{2}$ is a strong trigger of tyrosine phosphorylation of several egg proteins, including an Src protein. Further, brief treatment of Xenopus eggs with $\mathrm{H}_{2} \mathrm{O}_{2}$ leads to $\mathrm{Ca}^{2+}$ release and egg activation via activation of PLC $\gamma$ in the eggs (Sato et al. 2001). To examine whether a similar signaling pathway is operational in mouse eggs, we treated mouse eggs with $\mathrm{H}_{2} \mathrm{O}_{2}$ at 1, 10, and $100 \mu \mathrm{M}$ for 10,20 and 30 min. Importantly, mouse eggs treated with $\mathrm{H}_{2} \mathrm{O}_{2}$ under any of these conditions did not exhibit $\mathrm{Ca}^{2+}$ release or signs of egg activation (data not shown). However, when Western blotting was performed, it was found that tyrosine phosphorylation was greatly enhanced in eggs treated with $10 \mu \mathrm{M} \mathrm{H}_{2} \mathrm{O}_{2}$ for $10 \mathrm{~min}$, and that this phosphorylation was fully blocked in the presence of PP2 (Fig. 5G).

\section{Sperm-induced $\left[\mathrm{Ca}^{2+}\right]_{i}$ oscillations are not prevented by PP2}

The above results indicated that activation of an SFK is neither necessary nor sufficient for triggering $\left[\mathrm{Ca}^{2+}\right]_{i}$ oscillations and egg activation in mouse fertilization. To further support this conclusion, we performed mouse ICSI using sperm and eggs that were both pre-incubated with PP2 or PP3 prior to injection. As expected, when PP2-treated eggs were fertilized by PP2-treated sperm and further cultured in the presence of PP2, $\left[\mathrm{Ca}^{2+}\right]_{i}$ oscillations were not different from those seen with PP3 treatment (Fig. 7A and B), and egg activation also took place normally in both PP2- and PP3-treated eggs (data not shown).

\section{Discussion}

Recent evidence in echinoderm, ascidian, Xenopus, and zebrafish eggs suggests that activation of an SFK(s) is
Figure 7 PP2 does not prevent $\left[\mathrm{Ca}^{2+}\right]_{i}$ oscillations generated by sperm. Injection of a single mouse sperm into eggs pre-incubated with $5 \mu \mathrm{M}$ PP3 (A) or PP2 (B) for 30 min results in $\left[\mathrm{Ca}^{2+}\right]_{i}$ oscillations that are similar to those seen in untreated control eggs (see Fig. 6B). Pre-incubation was performed in the absence of oil. ICSI and $\left[\mathrm{Ca}^{2+}\right]_{i}$ monitoring were carried out in the presence of the inhibitors.

Arrows indicate time of injection; numbers of replicates are shown in each graph.

triggered upon fertilization, which in turn activates PLC $\gamma$ in the eggs, leading to $\mathrm{Ca}^{2+}$ release and egg activation (Abassi et al. 2000, Giusti et al. 2000, Runft \& Jaffe 2000, Sato et al. 2000, Wu \& Kinsey 2000). Previous studies showed that PLC $\gamma 1$ and 2 isoforms are expressed at the protein level in mouse eggs (Dupont et al. 1996, Mehlmann et al. 1998); thus, a similar mechanism could operate in mammals. In the present study, we have investigated whether activation of an $\mathrm{SFK}(\mathrm{s})$ is required for initiation of $\left[\mathrm{Ca}^{2+}\right]_{i}$ oscillations in mammalian fertilization using mouse gametes and porcine sperm as models. Our results have shown the following: (i) although a Hck-like protein and various tyrosine-phosphorylated proteins were detected in porcine sperm fractions, the presence of these proteins did not correspond to the active fractions of pSE; 
(ii) $\left[\mathrm{Ca}^{2+}\right]_{i}$ oscillations induced by $\mathrm{pSE}^{\mathrm{C}}$ in mouse eggs were unaltered by pre-incubation of pSE with specific tyrosine kinase inhibitors such as PP2 or lavendustin A, despite the fact that these inhibitors were shown to be active both in vivo and in vitro. Likewise, pre-injection or pre-incubation of eggs with these inhibitors did not affect the ability of $\mathrm{pSE}^{\mathrm{C}}$ to trigger $\left[\mathrm{Ca}^{2+}\right]_{i}$ oscillations in mouse eggs; (iii) microinjection of a recombinant c-Src protein or expression of mRNAs encoding constitutively active Src proteins did not induce $\mathrm{Ca}^{2+}$ release or egg activation; (iv) when ICSI was performed using sperm and eggs, both of which were pre-treated with $\mathrm{PP} 2,\left[\mathrm{Ca}^{2+}\right]_{i}$ oscillations occurred normally. Our results indicated that activation of an SFK is neither necessary nor sufficient for triggering $\left[\mathrm{Ca}^{2+}\right]_{\mathrm{i}}$ oscillations during mammalian fertilization.

\section{Hck-like protein and tyrosine-phosphorylated proteins in porcine sperm fractions}

It is well established that injection of sperm extracts from mouse or other species into mouse eggs can trigger fertilization-like $\left[\mathrm{Ca}^{2+}\right]_{i}$ oscillations and egg activation (Fissore et al. 1998, 2002, Swann et al. 2001). However, the identity of the molecule(s) that is delivered from the sperm and that is responsible for initiation of $\left[\mathrm{Ca}^{2+}\right]_{i}$ oscillations still remains to be fully elucidated. In support of the possibility that the fertilizing sperm delivers an SFK to the egg, to date expression of three SFKs, c-Abl, c-Src, and c-Yes, has been reported in human and rat sperm (Zhao et al. 1993, Nishio et al. 1995, Naz 1998, Leclerc \& Goupil 2002). Therefore, we first sought to determine which, if any, SFKs are present in $\mathrm{pSE}^{\mathrm{C}}$. We detected a Hck-like protein in soluble $\mathrm{pSE}^{\mathrm{C}}$ and significant amounts of tyrosine-phosphorylated proteins in the less soluble fractions, $\mathrm{pSE}^{\mathrm{TX}}$ and $\mathrm{pSE}^{\mathrm{pH}}$. Moreover, in vitro kinase assays showed that there was an ATP-dependent increase in protein phosphotyrosine content in the less soluble sperm fractions, and this increase was antagonized by PP2, further suggesting the presence of an active SFK(s) in porcine sperm. However, the localization of this Hck-like protein and other tyrosine-phosphorylated proteins did not correspond with all of the $\mathrm{Ca}^{2+}$-active pSE fractions following Superose 12 column elution. Therefore, our results suggested that if the $\left[\mathrm{Ca}^{2+}\right]_{i}$ oscillation-inducing sperm factor is a single molecule, then this molecule is unlikely to be an SFK. Furthermore, we showed that inhibition of the sperm SFK(s) by PP2 or lavendustin A did not affect the ability of $\mathrm{pSE}^{\mathrm{C}}$ to trigger $\left[\mathrm{Ca}^{2+}\right]_{i}$ oscillations, confirming the result that $a$ sperm SFK(s) is not essential for $\left[\mathrm{Ca}^{2+}\right]_{i}$ oscillations induced by injection of pSE. It is well documented that protein tyrosine phosphorylation is increased during sperm capacitation and the acrosome reaction, and is a critical process that regulates these events in many species (Evans \& Florman 2002, Visconti et al. 2002). Therefore, although our results indicated the presence of a Hck-like protein and, potentially, other active SFKs in porcine sperm fractions, it is more likely that these proteins, together with other SFKs that reportedly are present in sperm, are involved in the capacitation/acrosome reaction-related increase in protein phosphotyrosine content rather than in fertilization-associated $\left[\mathrm{Ca}^{2+}\right]_{i}$ oscillations (Leclerc \& Goupil 2002, Dorval et al. 2003).

\section{Activation of an egg SFK is not necessary for initiation of $\left[\mathrm{Ca}^{2+}\right]_{i}$ oscillations}

Although a sperm SFK(s) is unlikely to be responsible for $\left[\mathrm{Ca}^{2+}\right]_{\mathrm{i}}$ Oscillations triggered by injection of pSE, it is possible that an egg SFK(s) is directly or indirectly activated by a factor present in pSE which, in turn, stimulates activation of PLC $\gamma$ isoforms in the egg. It should be noted that activation of an egg SFK(s) is observed soon after fertilization and is essential for sperm-induced $\left[\mathrm{Ca}^{2+}\right]_{i}$ release and egg activation in sea urchin, zebrafish, and Xenopus (Kinsey 1996, Sato et al. 1999, 2000, Abassi et al. 2000, Wu \& Kinsey 2000). The importance of activation of an egg SFK(s) has also been demonstrated in starfish and ascidian (Giusti et al. 1999, 2000, Runft \& Jaffe 2000). It has been shown that in ascidian, starfish, and Xenopus eggs, inhibition of SFK signaling by the SFK SH2 domain or various SFK inhibitors, such as PP2, lavendustin A, and peptide A, prevents fertilization-associated $\left[\mathrm{Ca}^{2+}\right]_{i}$ release and egg activation via a PLC $\gamma$-dependent mechanism (Glahn et al. 1999, Sato et al. 2000). Importantly, the presence of the SFK members c-Abl, c-Fyn, and c-Yes has been reported in rat and mouse eggs (Talmor et al. 1998, Sutovsky et al. 2001, Talmor-Cohen et al. 2004 (this issue)). Moreover, in rat eggs, an increase in tyrosine phosphorylation of several proteins was observed shortly after fertilization (Ben-Yosef et al. 1998). However, in the present study, we have demonstrated that activation of an egg SFK(s) is not necessary for $\left[\mathrm{Ca}^{2+}\right]_{i}$ oscillations in mouse eggs induced by injection of pSE. When mouse eggs were pre-injected or pre-incubated with $\mathrm{PP} 2$, lavendustin $\mathrm{A}$, or peptide $\mathrm{A}$, $p S E^{\mathrm{C}}$-induced $\left[\mathrm{Ca}^{2+}\right]_{i}$ oscillations occurred normally, despite the fact that these inhibitors were proven to function in vitro (Fig. 4F) and in vivo (Fig. 5G). In addition, it should be noted that these inhibitors were reported to completely block sperm-induced $\left[\mathrm{Ca}^{2+}\right]_{\mathrm{i}}$ release in Xenopus at the same, or even lower, concentrations than those that we used (Glahn et al. 1999, Sato et al. 2002).

\section{Activation of an SFK is not sufficient for initiation of $\left[\mathrm{Ca}^{2+}\right]_{i}$ oscillations}

Lastly, we tested the possibility that activation of an SFK(s) is sufficient to trigger $\left[\mathrm{Ca}^{2+}\right]_{i}$ oscillations and/or egg activation in the mouse. It has been demonstrated that, in starfish and Xenopus eggs, activation of an egg SFK(s) per se is sufficient to induce $\mathrm{Ca}^{2+}$ release and egg activation via PLC $\gamma$ activation (Giusti et al. 2000, Tokmakov et al. 2002, Sato et al. 2003). Our results show that neither injection of active Src protein nor expression of mRNAs encoding constitutively active $\mathrm{Src}$ mutants induced $\left[\mathrm{Ca}^{2+}\right]_{i}$ release or egg activation in mouse eggs. In vitro kinase assays proved 
that the recombinant protein used was active (Fig. 4F). Moreover, the eggs injected with the mRNAs showed an increase in protein phosphotyrosine content that was sensitive to inhibition by PP2, indicating that the introduced mRNAs were properly translated to active Src proteins in the eggs. It was recently demonstrated that $\mathrm{H}_{2} \mathrm{O}_{2}$ is a strong trigger of protein tyrosine phosphorylation and that $\mathrm{H}_{2} \mathrm{O}_{2}$ treatment of Xenopus eggs triggers $\left[\mathrm{Ca}^{2+}\right]_{i}$ release and egg activation via activation of the egg SFK, Xyk (Sato et al. 2001, 2003, Tokmakov et al. 2002). In contrast to Xenopus, however, our results showed that incubation of eggs with $\mathrm{H}_{2} \mathrm{O}_{2}$ did not cause any $\left[\mathrm{Ca}^{2+}\right]_{i}$ release or egg activation, even though different $\mathrm{H}_{2} \mathrm{O}_{2}$ concentrations and incubation times were applied. Nevertheless, the eggs treated with $\mathrm{H}_{2} \mathrm{O}_{2}$ exhibited a significant increase in protein phosphotyrosine content that was inhibited in the presence of $\mathrm{PP} 2$, indicating that $\mathrm{H}_{2} \mathrm{O}_{2}$ treatment triggered tyrosine phosphorylation of mouse egg proteins via activation of an egg SFK(s). Taken together, our results demonstrated that activation of an egg SFK(s) is not sufficient for initiation of $\left[\mathrm{Ca}^{2+}\right]_{i}$ oscillations or egg activation.

Nevertheless, contrary to our results, two groups have recently reported activation of mouse eggs via stimulation of an egg SFK. Sette et al. (2002) have proposed a hypothesis that the truncated c-kit tyrosine kinase (tr-kit) is delivered from the fertilizing sperm and activates c-Fyn in mouse eggs, leading, potentially, to stimulation of PLC $\gamma 1$ and subsequent $\left[\mathrm{Ca}^{2+}\right]_{i}$ responses and egg activation. Sette et al. (2002) showed that injection of the active c-Fyn mutant or tr-kit-expressing cell extracts into mouse eggs caused egg activation. Likewise, it was reported by another group that a novel protein in the sperm perinuclear theca, PT32, is able to induce egg activation in mouse eggs by interacting with and activating eggs' c-Yes (Sutovsky et al. 2001, Wu et al. 2001a). However, $\left[\mathrm{Ca}^{2+}\right]_{\mathrm{i}}$ measurements were not performed in either of those two studies. Thus, it is possible that excessive amounts of an active SFK(s) may be able to trigger egg activation independently of the $\mathrm{Ca}^{2+}$ signal (Talmor-Cohen et al. 2004 (this issue)). It should be noted that PP2 at the same concentration as that used to inhibit egg activation induced by the active c-Fyn mutant and tr-kit (Sette et al. 2002) did not block fertilization-triggered $\left[\mathrm{Ca}^{2+}\right]_{i}$ oscillations or egg activation in the present study. Therefore, the physiological significance of tr-kit- and PT32-induced signaling pathways remains unclear and requires further investigation.

\section{What is sperm factor?}

Recently, a novel sperm-specific PLC, PLC $\zeta$, was discovered and has been proposed to be the active $\mathrm{Ca}^{2+}$-releasing component of sperm factor (Saunders et al. 2002). PLC $\zeta$ mRNA is able to trigger $\left[\mathrm{Ca}^{2+}\right]_{i}$ oscillations in mouse eggs that are similar to those at fertilization (Saunders et al. 2002, present study). Nevertheless, it still remains to be fully elucidated whether PLC $\zeta$ represents all of the active components of sperm factor since the localization of this protein in sperm as well as the ability of the recombinant protein, instead of $m R N A$, to induce $\left[\mathrm{Ca}^{2+}\right]_{i}$ oscillations has not been shown (Swann et al. 2004 (this issue)). In the present study, we developed a new extraction method of pSE, whereby less soluble pSE $\left(\mathrm{pSE}^{\mathrm{TX}}\right.$ and $\left.\mathrm{pSE}^{\mathrm{pH}}\right)$, which remains in the sperm head after extraction of conventional soluble $\mathrm{pSE}^{\mathrm{C}}$, could be recovered. These less soluble pSE fractions appear to have different protein profiles from those of conventional soluble $\mathrm{pSE}^{\mathrm{C}}$ since both $\mathrm{pSE}^{\mathrm{TX}}$ and $\mathrm{pSE}^{\mathrm{pH}}$ contained significantly greater amounts of protein phosphotyrosine content. It would therefore be of particular interest to determine whether or not PLC $\zeta$ is equally present in soluble and less soluble pSEs.

We also found that peptide A, originally created as an inhibitor of SFKs, was able to prevent the $\left[\mathrm{Ca}^{2+}\right]_{i}$ oscillation-inducing activity of $\mathrm{pSE}^{\mathrm{C}}$ only when incubated with the extracts, despite the discrepancy that activation of an $\mathrm{SFK}(\mathrm{s})$ is unlikely to be required for the initiation of $\left[\mathrm{Ca}^{2+}\right]_{i}$ oscillations in mouse fertilization. A possible explanation for this is that the active $\left[\mathrm{Ca}^{2+}\right]_{i}$ oscillationinducing molecule(s) in $\mathrm{pSE}^{\mathrm{C}}$ may contain a domain that is highly similar to the peptide A-binding domain present in SFKs. Nevertheless, regardless of the lack of involvement of an SFK(s) in mouse fertilization, it is significant that peptide $A$ is the first reagent capable of inhibiting pSE-induced $\left[\mathrm{Ca}^{2+}\right]_{i}$ oscillations. Currently, we are investigating whether or not PLC $\zeta$ activity is inhibited by this peptide.

In summary, our results have demonstrated that, in contrast to the mechanisms in invertebrates and Xenopus, activation of an SFK(s) is neither necessary nor sufficient for fertilization-induced $\left[\mathrm{Ca}^{2+}\right]_{i}$ oscillations in the mouse. However, it should be noted that our results do not necessarily discount the possibility that activation of PLC $\gamma$ isoforms is required for fertilization-associated $\left[\mathrm{Ca}^{2+}\right]_{\mathrm{i}}$ oscillations in the mouse. Although PLC $\zeta$ certainly is a strong candidate as the trigger of the oscillations, it is not clear whether it is the sole molecule required for initiation of $\left[\mathrm{Ca}^{2+}\right]_{i}$ oscillations. Therefore, the mechanism leading to initiation of $\left[\mathrm{Ca}^{2+}\right]_{i}$ oscillations at fertilization still remains to be fully elucidated.

\section{Note added in proof}

While this paper was in preparation, a paper appeared in the Journal of Biological Chemistry in the form of papers in press: Kouchi et al. "Recombinant phospholipase $\mathrm{C}$-zeta has high $\mathrm{Ca}^{2+}$-sensitivity and induces $\mathrm{Ca}^{2+}$ oscillations in mouse eggs". The authors showed that injections of high concentration of recombinant PLC $\zeta$ protein into mouse eggs triggered $\left[\mathrm{Ca}^{2+}\right]_{i}$ oscillations, whereas injection of PLC $\delta 1$ protein failed to do so.

\section{Acknowledgements}

We thank Dr Joan S Brugge (Harvard Medical School) for providing the Src cDNA constructs. We also thank the 
members of our laboratories for critical reading of the manuscript and discussion. This work was supported by grants from USDA (99-2371 and 02-2078) and USDA/Hatch to R A $\mathrm{F}$, a Lalor Foundation fellowship to $\mathrm{M} \mathrm{K}$, and grants from the Japanese Ministry of Education, Science, Culture, Sports, and Technology to K S.

\section{References}

Abassi YA, Carroll DJ, Giusti AF, Belton RJ Jr \& Foltz KR 2000 Evidence that Src-type tyrosine kinase activity is necessary for initiation of calcium release at fertilization in sea urchin eggs. Developmental Biology 218 206-219.

Ben-Yosef D, Talmor A, Shwartz L, Granot Y \& Shalgi R 1998 Tyrosyl-phosphorylated proteins are involved in regulation of meiosis in the rat egg. Molecular Reproduction and Development 49 176-185.

Carroll DJ, Ramarao CS, Mehlmann LM, Roche S, Terasaki M \& Jaffe LA 1997 Calcium release at fertilization in starfish eggs is mediated by phospholipase C $\gamma$. Journal of Cell Biology 138 1303-1311.

Carroll DJ, Albay DT, Terasaki M, Jaffe LA \& Foltz KR 1999 Identification of PLC $\gamma$-dependent and -independent events during fertilization of sea urchin eggs. Developmental Biology 206 232-247.

Coward K, Campos-Mendoza A, Larman M, Hibbitt O, McAndrew B, Bromage N \& Parrington J 2003 Teleost fish spermatozoa contain a cytosolic protein factor that induces calcium release in sea urchin egg homogenates and triggers calcium oscillations when injected into mouse oocytes. Biochemical and Biophysical Research Communications 305 299-304.

Cox LJ, Larman MG, Saunders CM, Hashimoto K, Swann K \& Lai FA 2002 Sperm phospholipase $C \zeta$ from humans and cynomolgus monkeys triggers $\mathrm{Ca}^{2+}$ oscillations, activation and development of mouse oocytes. Reproduction 124 611-623.

Dong JB, Tang TS \& Sun FZ 2000 Xenopus and chicken sperm contain a cytosolic soluble protein factor which can trigger calcium oscillations in mouse eggs. Biochemical and Biophysical Research Communications 268 947-951.

Dorval V, Dufour M \& Leclerc P 2003 Role of protein tyrosine phosphorylation in the thapsigargin-induced intracellular $\mathrm{Ca}^{2+}$ store depletion during human sperm acrosome reaction. Molecular Human Reproduction 9 125-131.

Dupont G, McGuinness OM, Johnson MH, Berridge MJ \& Borgese F 1996 Phospholipase $C$ in mouse oocytes: characterization of $\beta$ and $\gamma$ isoforms and their possible involvement in sperm-induced $\mathrm{Ca}^{2+}$ spiking. Biochemical Journal 316 583-591.

Evans JP \& Florman HM 2002 The state of the union: the cell biology of fertilization. Nature Cell Biology 4 S57-S63.

Fissore RA, He CL \& Vande Woude GF 1996 Potential role of mitogen-activated protein kinase during meiosis resumption in bovine oocytes. Biology of Reproduction 55 1261-1270.

Fissore RA, Gordo AC \& Wu H 1998 Activation of development in mammals: is there a role for a sperm cytosolic factor? Theriogenology 49 43-52.

Fissore RA, Kurokawa M, Knott J, Zhang M \& Smyth J 2002 Mechanisms underlying oocyte activation and postovulatory ageing. Reproduction 124 745-754.

Fujiki Y, Hubbard AL, Fowler S \& Lazarow PB 1982 Isolation of intracellular membranes by means of sodium carbonate treatment: application to endoplasmic reticulum. Journal of Cell Biology 93 97-102.

Fukami K, Nakao K, Inoue T, Kataoka Y, Kurokawa M, Fissore RA, Nakamura K, Katsuki M, Mikoshiba K, Yoshida N \& Takenawa T 2001 Requirement of phospholipase C 84 for the zona pellucidainduced acrosome reaction. Science 292 920-923.

Fukami Y, Sato K, Ikeda K, Kamisango K, Koizumi K \& Matsuno T 1993 Evidence for autoinhibitory regulation of the c-src gene product. A possible interaction between the src homology 2 domain and autophosphorylation site. Journal of Biological Chemistry $2681132-1140$.

Giusti AF, Carroll DJ, Abassi YA, Terasaki M, Foltz KR \& Jaffe LA 1999 Requirement of a Src family kinase for initiating calcium release at fertilization in starfish eggs. Journal of Biological Chemistry $27429318-29322$.

Giusti AF, Xu W, Hinkle B, Terasaki M \& Jaffe LA 2000 Evidence that fertilization activates starfish eggs by sequential activation of a Src-like kinase and phospholipase C $\gamma$. Journal of Biological Chemistry 275 16788-16794.

Glahn D, Mark SD, Behr RK \& Nuccitelli R 1999 Tyrosine kinase inhibitors block sperm-induced egg activation in Xenopus laevis. Developmental Biology 205 171-180.

He CL, Damiani P, Parys JB \& Fissore RA 1997 Calcium, calcium release receptors, and meiotic resumption in bovine oocytes. Biology of Reproduction 57 1245-1255.

Jellerette T, He CL, Wu H, Parys JB \& Fissore RA 2000 Down-regulation of the inositol 1,4,5-trisphosphate receptor in mouse eggs following fertilization or parthenogenetic activation. Developmental Biology 223 238-250.

Jones KT, Cruttwell C, Parrington J \& Swann K 1998 A mammalian sperm cytosolic phospholipase $\mathrm{C}$ activity generates inositol trisphosphate and causes $\mathrm{Ca}^{2+}$ release in sea urchin egg homogenates. FEBS Letters 437 297-300.

Jones KT, Matsuda M, Parrington J, Katan M \& Swann K 2000 Different $\mathrm{Ca}^{2+}$-releasing abilities of sperm extracts compared with tissue extracts and phospholipase $C$ isoforms in sea urchin egg homogenate and mouse eggs. Biochemical Journal 346 743-749.

Kimura Y \& Yanagimachi R 1995 Intracytoplasmic sperm injection in the mouse. Biology of Reproduction 52 709-720.

Kimura Y, Yanagimachi R, Kuretake S, Bortkiewicz H, Perry AC \& Yanagimachi H 1998 Analysis of mouse oocyte activation suggests the involvement of sperm perinuclear material. Biology of Reproduction 58 1407-1415.

Kinsey WH 1996 Biphasic activation of Fyn kinase upon fertilization of the sea urchin egg. Developmental Biology 174 281-287.

Kouchi Z, Fukami K, Shikano T, Oda S, Nakamura Y, Takenawa T \& Miyazaki S 2004 Recombinant phospholipase C-zeta has high $\mathrm{Ca}^{2+}$-sensitivity and induces $\mathrm{Ca}^{2+}$ oscillations in mouse eggs. Journal of Biological Chemistry (In Press).

Kuroda R, Kontani K, Kanda Y, Katada T, Nakano T, Satoh Y, Suzuki N \& Kuroda H 2001 Increase of cGMP, cADP-ribose and inositol 1,4,5-trisphosphate preceding $\mathrm{Ca}^{2+}$ transients in fertilization of sea urchin eggs. Development 128 4405-4414.

Kurokawa M \& Fissore RA 2003 ICSI-generated mouse zygotes exhibit altered calcium oscillations, inositol 1,4,5-trisphosphate receptor-1 down-regulation, and embryo development. Molecular Human Reproduction 9 523-533.

Leclerc P \& Goupil S 2002 Regulation of the human sperm tyrosine kinase c-yes. Activation by cyclic adenosine 3',5'-monophosphate and inhibition by $\mathrm{Ca}^{2+}$. Biology of Reproduction 67 301-307.

Lee SJ \& Shen SS 1998 The calcium transient in sea urchin eggs during fertilization requires the production of inositol 1,4,5-trisphosphate. Developmental Biology 193 195-208.

Li ST, Huang XY \& Sun FZ 2001 Flowering plant sperm contains a cytosolic soluble protein factor which can trigger calcium oscillations in mouse eggs. Biochemical and Biophysical Research Communications 287 56-59.

Mehlmann LM, Carpenter G, Rhee SG \& Jaffe LA 1998 SH2 domainmediated activation of phospholipase $\mathrm{C}_{\boldsymbol{\gamma}}$ is not required to initiate $\mathrm{Ca}^{2+}$ release at fertilization of mouse eggs. Developmental Biology $203221-232$.

Miyazaki S, Yuzaki M, Nakada K, Shirakawa H, Nakanishi S, Nakade S \& Mikoshiba K 1992 Block of $\mathrm{Ca}^{2+}$ wave and $\mathrm{Ca}^{2+}$ oscillation by antibody to the inositol 1,4,5-trisphosphate receptor in fertilized hamster eggs. Science 257 251-255.

Naz RK 1998 c-Abl proto-oncoprotein is expressed and tyrosine phosphorylated in human sperm cell. Molecular Reproduction and Development 51 210-217. 
Nishio H, Tokuda M, Itano T, Matsui H, Takeuchi Y \& Hatase $\mathbf{O}$ 1995 pp60 $^{\text {c-src }}$ expression in rat spermatogenesis. Biochemical and Biophysical Research Communications 206 502-510.

Oda S, Deguchi R, Mohri T, Shikano T, Nakanishi S \& Miyazaki S 1999 Spatiotemporal dynamics of the $\left[\mathrm{Ca}^{2+}\right]_{i}$ rise induced by microinjection of sperm extract into mouse eggs: preferential induction of $\mathrm{a} \mathrm{Ca}^{2+}$ wave from the cortex mediated by the inositol 1,4,5-trisphosphate receptor. Developmental Biology 209 $172-185$.

Parrington J, Jones KT, Lai A \& Swann K 1999 The soluble sperm factor that causes $\mathrm{Ca}^{2+}$ release from sea-urchin (Lytechinus pictus) egg homogenates also triggers $\mathrm{Ca}^{2+}$ oscillations after injection into mouse eggs. Biochemical Journal 341 1-4.

Parrington J, Jones ML, Tunwell R, Devader C, Katan M \& Swann K 2002 Phospholipase C isoforms in mammalian spermatozoa: potential components of the sperm factor that causes $\mathrm{Ca}^{2+}$ release in eggs. Reproduction 123 31-39.

Rice A, Parrington J, Jones KT \& Swann K 2000 Mammalian sperm contain a $\mathrm{Ca}^{2+}$-sensitive phospholipase $\mathrm{C}$ activity that can generate InsP $_{3}$ from $\mathrm{PIP}_{2}$ associated with intracellular organelles. Developmental Biology 228 125-135.

Runft LL \& Jaffe LA 2000 Sperm extract injection into ascidian eggs signals $\mathrm{Ca}^{2+}$ release by the same pathway as fertilization. Development 127 3227-3236.

Runft LL, Watras J \& Jaffe LA 1999 Calcium release at fertilization of Xenopus eggs requires type $\mathrm{I}_{\mathrm{IP}}$ receptors, but not $\mathrm{SH} 2$ domainmediated activation of PLC $\gamma$ or $\mathrm{G}_{\mathrm{q}}$-mediated activation of PLC $\beta$. Developmental Biology 214 399-411.

Sato K, Miki S, Tachibana H, Hayashi F, Akiyama T \& Fukami Y 1990 A synthetic peptide corresponding to residues 137 to 157 of p60vsrc inhibits tyrosine-specific protein kinases. Biochemical and Biophysical Research Communications 171 1152-1159.

Sato K, Iwao Y, Fujimura T, Tamaki I, Ogawa K, Iwasaki T, Tokmakov AA, Hatano O \& Fukami Y 1999 Evidence for the involvement of a Src-related tyrosine kinase in Xenopus egg activation. Developmental Biology 209 308-320.

Sato K, Tokmakov AA, Iwasaki T \& Fukami Y 2000 Tyrosine kinasedependent activation of phospholipase $\mathrm{C} \gamma$ is required for calcium transient in Xenopus egg fertilization. Developmental Biology 224 453-469.

Sato K, Ogawa K, Tokmakov AA, Iwasaki T \& Fukami Y 2001 Hydrogen peroxide induces Src family tyrosine kinase-dependent activation of Xenopus eggs. Development Growth and Differentiation $4355-72$.

Sato K, Iwasaki T, Ogawa K, Konishi M, Tokmakov AA \& Fukami Y 2002 Low density detergent-insoluble membrane of Xenopus eggs: subcellular microdomain for tyrosine kinase signaling in fertilization. Development 129 885-896.

Sato KI, Tokmakov AA, He CL, Kurokawa M, Iwasaki T, Shirouzu M, Fissore RA, Yokoyama S \& Fukami Y 2003 Reconstitution of Srcdependent PLC $\gamma$ phosphorylation and transient calcium release by using membrane rafts and cell-free extracts from Xenopus eggs. Journal of Biological Chemistry 278 38413-38420.

Saunders CM, Larman MG, Parrington J, Cox LJ, Royse J, Blayney LM, Swann K \& Lai FA 2002 PLC $\zeta$ : a sperm-specific trigger of $\mathrm{Ca}^{2+}$ oscillations in eggs and embryo development. Development $1293533-3544$

Sette C, Paronetto MP, Barchi M, Bevilacqua A, Geremia R \& Rossi P 2002 Tr-kit-induced resumption of the cell cycle in mouse eggs requires activation of a Src-like kinase. EMBO Journal 21 5386-5395.

Shearer J, De Nadai C, Emily-Fenouil F, Gache C, Whitaker M \& Ciapa B 1999 Role of phospholipase $C \gamma$ at fertilization and during mitosis in sea urchin eggs and embryos. Development 126 2273-2284.

Snow P, Yim DL, Leibow JD, Saini S \& Nuccitelli R 1996 Fertilization stimulates an increase in inositol trisphosphate and inositol lipid levels in Xenopus eggs. Developmental Biology $\mathbf{1 8 0}$ $108-118$

Stith BJ, Goalstone M, Silva S \& Jaynes C 1993 Inositol 1,4,5-trisphosphate mass changes from fertilization through first cleavage in Xenopus laevis. Molecular Biology of the Cell 4 435-443.

Stricker SA, Swann K, Jones KT \& Fissore RA 2000 Injections of porcine sperm extracts trigger fertilization-like calcium oscillations in oocytes of a marine worm. Experimental Cell Research 257 $341-347$.

Sutovsky P, Wu A, Takahashi D, Benmusa A, Schatten G, Dominko T \& Oko R 2001 Oocyte activation by mammalian sperm perinuclear theca protein PT32 and tyrosine kinase c-Yes. Molecular Biology of the Cell 12 (Suppl) 114a.

Swann K, Parrington J \& Jones KT 2001 Potential role of a spermderived phospholipase $\mathrm{C}$ in triggering the egg-activating $\mathrm{Ca}^{2+}$ signal at fertilization. Reproduction 122 839-846.

Swann K, Larman MG, Saunders CM \& Lai FA 2004 The cytosolic sperm factor that triggers $\mathrm{Ca}^{2+}$ oscillations and egg activation in mammals is a novel phospholipase C: PLC $\zeta$. Reproduction 127 431-439.

Talmor A, Kinsey WH \& Shalgi R 1998 Expression and immunolocalization of $\mathrm{p} 59^{\mathrm{c}-\mathrm{fyn}}$ tyrosine kinase in rat eggs. Developmental Biology 194 38-46.

Talmor-Cohen A, Tomashov-Matar R, Eliyahu E, Shapiro R \& Shalgi R 2004 Are Src family kinases involved in cell cycle resumption in rat eggs? Reproduction 127 455-463.

Tokmakov AA, Sato KI, Iwasaki T \& Fukami Y 2002 Src kinase induces calcium release in Xenopus egg extracts via PLC $\gamma$ and $\mathrm{IP}_{3^{-}}$ dependent mechanism. Cell Calcium 32 11-20.

Visconti PE, Westbrook VA, Chertihin O, Demarco I, Sleight S \& Diekman AB 2002 Novel signaling pathways involved in sperm acquisition of fertilizing capacity. Journal of Reproductive Immunology 53 133-150.

Walker EM, Bispham JR \& Hill SJ 1998 Nonselective effects of the putative phospholipase C inhibitor, U73122, on adenosine A1 receptor-mediated signal transduction events in Chinese hamster ovary cells. Biochemical Pharmacology 56 1455-1462.

Wu A, Sutovsky P, Dominko T, Schatten G, Gong J \& Oko R 2001 a PT32, a candidate for a sperm borne-egg activating factor. Journal of Andrology 22 (Suppl) 95.

Wu H, He CL \& Fissore RA 1997 Injection of a porcine sperm factor triggers calcium oscillations in mouse oocytes and bovine eggs. Molecular Reproduction and Development 46 176-189.

Wu H, He CL, Jehn B, Black SJ \& Fissore RA 1998a Partial characterization of the calcium-releasing activity of porcine sperm cytosolic extracts. Developmental Biology 203 369-381.

Wu H, He CL \& Fissore RA $1998 b$ Injection of a porcine sperm factor induces activation of mouse eggs. Molecular Reproduction and Development 49 37-47.

Wu H, Smyth J, Luzzi V, Fukami K, Takenawa T, Black SL, Allbritton NL \& Fissore RA 2001 b Sperm factor induces intracellular free calcium oscillations by stimulating the phosphoinositide pathway. Biology of Reproduction 64 1338-1349.

Wu W \& Kinsey WH 2000 Fertilization triggers activation of Fyn kinase in the zebrafish egg. International Journal of Developmental Biology 44 837-841.

Yule DI \& Williams JA 1992 U73122 inhibits $\mathrm{Ca}^{2+}$ oscillations in response to cholecystokinin and carbachol but not to JMV-180 in rat pancreatic acinar cells. Journal of Biological Chemistry 267 13830-13835.

Zhao Y, Uyttendaele H, Krueger JG, Sudol M \& Hanafusa H 1993 Inactivation of $\mathrm{C}$-Yes tyrosine kinase by elevation of intracellular calcium levels. Molecular Biology of the Cell 13 7507-7514.

Received 1 December 2003

First decision 8 January 2004

Accepted 30 January 2004 